\title{
TITLE:
}

\section{OBSERVATIONS AND DISCUSSIONS ON THE SOCIAL BEHAVIORS OF MARINE FISHES}

$\operatorname{AUTHOR}(\mathrm{S})$ :

Okuno, Ryonosuke

CITATION:

Okuno, Ryonosuke. OBSERVATIONS AND DISCUSSIONS ON THE SOCIAL BEHAVIORS OF MARINE FISHES. PUBLICATIONS OF THE SETO MARINE BIOLOGICAL LABORATORY 1963,

$11(2): 281-336$

ISSUE DATE:

1963-12-31

URL:

http://hdl.handle.net/2433/175341

RIGHT: 


\title{
OBSERVATIONS AND DISCUSSIONS ON THE SOCIAL BEHAVIORS OF MARINE FISHES
}

\author{
RYÔNOSUKE OKUNO
}

Suma Aquarium of Kobe City

With 23 Tables and 6 Text-figures

CONTENTS

2. Material and Method $. \ldots \ldots \ldots \ldots \ldots \ldots \ldots . . .281$

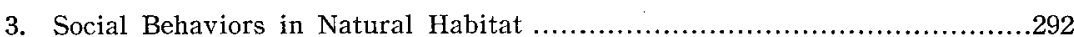

Four bchavior types of marine fishes ..................................292

Descriptions of social behaviors of some fishes ........................293

Considerations on the social behaviors in natural habitats.................304

4. Schooling Behavior in the Big Tank ..........................................

Observations on the schooling behavior of some marine fishes ...........305

Relationships between Girella punctata and $G$. melanichthys in regard to their schooling habits .........................................309

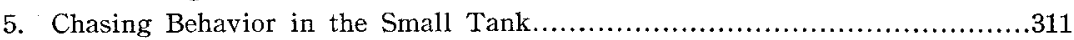

Changes of fish behavior in captivity ................................311

Intra- and interspecific relations of fish chasing in capativity ............313

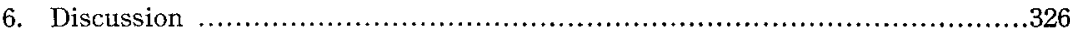

Social behaviors of fishes in the small tank contra those in their natural habitats ..............................................326

Some aspects on the social behaviors of fishes ..........................330

Schooling behaviors of marine fishes in relation to their habitats ......331

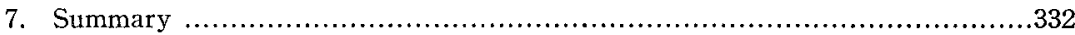

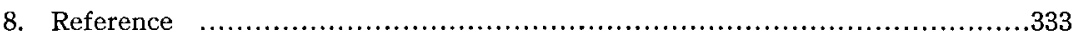

\section{Introduction}

The social structures has been considered to be one of the most interesting items in animal ecology in recent decades. It is said that the vertebrate sociology was started in 1922 by ScHJELDERUP-EBBE's study of the hierarchy of chickin. AlleE and his associates expanded their works on vertebrate sociology from fish to mammal. And in recent years, the interest of animal

1) Contributions from the Seto Marine Biological Laboratory, No. 404.

2) Contributions from the Suma Aquarium of Kobe City, No. 35.

Publ. Seto Mar. Biol. Lab., XI (2), 1963. (Article 17) 
sociologists seems to be concentrated in the social structure of mammals, especially of primates. Highly developed social organizations and behaviors in mammals are apparently related to their well-developed cerebrum or forebrain. In fishes, too, some social behaviors may accord with the development of the forebrain. HALE (1956) reported that the quantitative reduction of aggressive behavior following the destruction of most parts of forebrain was found in green sunfish and goldfish. Hillowitz (1945) and Berman (1945) suggested that the WELTY-type maze (WELTY, 1934) of fish without forebrain was slower than in normal fish. But, in fishes the development of forebrain is considered to be rather poor to evolve those higher social behaviors. Therefore, the essential nature or principle of the social organization of lower vertebrates might differ from those of mammals with highly developed forebrain.

Sociological studies of fishes have been promoted in various ways. Dominance-subordination relationship or social hierarchy was analysed mainly on animals in captivity (Allee and Dickinson, 1954, Braddock, 1945 and 1949, etc.). Territory or territoriality was observed both in the natural and indoor conditions (Kalleberg, 1958, Kawabata, 1954, Kawanabe, 1957, '58, '59 and '60, Kawanabe et al., 1956, '57 and Miyadi et al., 1952). Relationships between hierarchy and territoriality were suspected by GREENBERG (1947) and MoRI (1956) through the experiments with fishes in capitivity. Most of these experiments were made with freshwater fishes except for MoRI's (1956). On the other hand, social behaviors of marine fishes were observed by BREDER (1951 and 1959), Shaw (1960 and 1962) and Hiatt and Strasburg (1960). Breder pointed out on the basis of his enormous data that four behaviors types were distinguishable, namely solitray, aggregating, schooling and pod making ones. Of these, he studied especially on the schooling behaviors under the experimental conditions as well as in natural habitats. SHAw examined the development of schooling behavior in the fishes of the genus Menidia. Hiatt and Strasburg observed the ecological relationships found among the fishes living on the coral reefs of the Marshall Islands and classified the social behaviors of those fishes into solitary, schooling and aggregating ones.

On the other hand, it has been known that some fishes change their natural behaviors when they are kept in a limited space. For instance, young fishes of Girella punctata show the schooling behavior on the natural rocky reefs but in a limited circumstance they show the territorial habit or social hierarchy established by mutual fightings (MORI, 1956 and OKUnO, 1956 b). Oryzias latipes, a small schooling fish common in any Japanese rivers, shows the territorial behavior when a certain number of fishes are kept in a small tank (KAWABATA, 1954 and MAGNUSON, 1962). Neither dominance-subordination relationship nor leadership is, however, recognized in any schools of these fishes in natural 
habitats (OKuno, $1956 \mathrm{~b}$ ). Thus, a social structure observed on a certain species of fish in a small aquarium can not always be accepted to represent its natural social structure. Comparative analyses must be made between the natural social behaviors and behaviors observed in small tanks to find out the essential feature of the social structure of fishes.

I have had many chances of making underwater divings with SCUBA from 1954 to 1962 on the southern coasts of Japan and succeeded to observe social behaviors of 117 species of reef fishes. Observations and some tests were made then on 216 species of fishes in tanks of various sizes at the Suma Aquarium of Kobe City in the years from 1957 to 1963 . Some parts of the records of the above-mentioned observations have already been published (Okuno, 1956 a, 1956 b, 1962 a, 1962 b, 1963, Okuno and Aoki, 1959, Okuno, Fuse and Harada, 1958, Okuno, Kurio and Nishiguchi, 1960, Okuno, Nishiguchi and KuRIO, 1961 and 1962).

I suggested in my previous paper (OKUnO, 1956 a) that the social behaviors of marine fishes could be divided into three groups: schooling, aggregative* and solitary ones. Similarly the chasing behaviors shown by fishes in small tanks could be divided into three types: intraspecific (chasing is done only against comrades belonging to the same species), nonspecific (chasing is done against fishes of other species as well as those of the same species) and interspecific (chasing is done only against fishes of other species) types (OKUno, 1963). And, it was found that schooling fishes belong to the intraspecific type while assembling fishes to the nonspecific type.

In the present paper, first the social behaviors of some marine fishes in their natural environments are described and compared one another. Then the schooling behavior of some of these fishes shown in the big tank are described in order to make it possible to analyze and appreciate exactly the data obtained by field observation. By the way, various types of chasing behavior presented by some fishes in the small tank are shown to enrich the data on this behavior referred in my previous papers (OKunO, $1962 \mathrm{a}$ and 1963). And finally some considerations are given on the social behaviors of marine teleosts in the field and aquarium, the relationships between the behaviors in these different circumstances being discussed.

In carrying out this study I owe much to many persons. First, I wish to express my deep gratitude to Prof. Denzaburo MiYadi of Kyoto University, for his kind guidance and helpful advices given to this study, and I want to record my hearty thanks to Dr. Takasi Tokioka of Seto Marine Biological Labolatory, for his kindness in giving me many valuable advices and in reading the manuscript. I also wish to express my thanks to Prof. Syuiti MorI of Otsu Hydrobiological Station, Prof. Huzio Utinomi of Seto Marine Biological

* The term "assemblage" will be used in this paper instead of "aggregation". 
Labolatory, Dr. Mitoshi Tokuda, Dr. Hiroya Kawanabe, Dr. Eiji Harada of Kyoto University, Dr. Tadashige Habe of National Science Museum, Dr. Kazuo Sibuy A of Ritsumeikan University, Prof. Kisaburo ONO of Kyoto Prefectural University of Medicine, Mr. Kiheiji Inoue, the directer, and Messrs. Keisei Yoshida, Kazuhiko Harashima, Kazutsugu Hirayama and Motoaki Shiomi of the Suma Aquarium for their kind advices and critisisms. Also my thanks are due to Prof. Toshiji Kamohara of Kôchi University and Mr. Chûichi Araga of the Sirahama Aquarium identifying some of the studied fishes. Lastly, it must be noted here that I have been much indebted to Mr. Sôhachi Iwaki, a fisherman in Shirahama, Mr. Toyohiko MaJima, an outstanding shell collector in the Amami Islands, Messrs. Isokichi and Hiroshi Амгмото, fishermen in Akashi City, Messrs. Masao Nishiguchi and Tetsuo Kurio of the Suma Aquarium for their kind assistance during field surveys.

\section{Material and Method}

\section{Material}

The social behaviors of 130 species of marine fishes covering 76 genera, 35 families, 12 suborders and 5 orders as shown in Table 1 are referred in the present study.

They are mostly rocky reef or coral reef fishes, especially of the suborders Percina, Pomocentrina, Labrina and Chaetodontina, but contain some of oceanic or sandy shore inhabitants. They were collected along the west coast of $\mathrm{Kii}$ Peninsula, in Osaka Bay, or in the waters of the Amami Islands and the Okinawa Islands and offered to us by fishermen or fish dealers, excepting some ones which were caught by the collecting group of the Suma Aquarium themselves.

For experiments in the tank, only healthy and well acclimatised fishes were used. I believe that these fishes were examined being scarcely stimulated by visitors or the observer, since they had been enough accustomed to be operated in the aquarium for so long time from a month to four years.

\section{Method}

The social behaviors of these fishes were investigated by means of direct observations which were made 1) in the sea, 2) in the big tank and 3) in the small tank. Most fishes in the big tank exhibit a similar social behavior as in the sea, while in the small tank they occasionally show a quite different behavior. Thus the fish behavior learned in the sea were assured by the supplement any date obtained in the big tank and then compared with those

$$
-{ }_{1}^{\prime} 114-
$$


Table 1. List of studied fishes arranged afterr the systematic order adopted in MAT'SUBARA's book (1955).

* F : Field observations carried out. B : Observations made in the big tank. $\mathrm{S}:$ in the small tank.

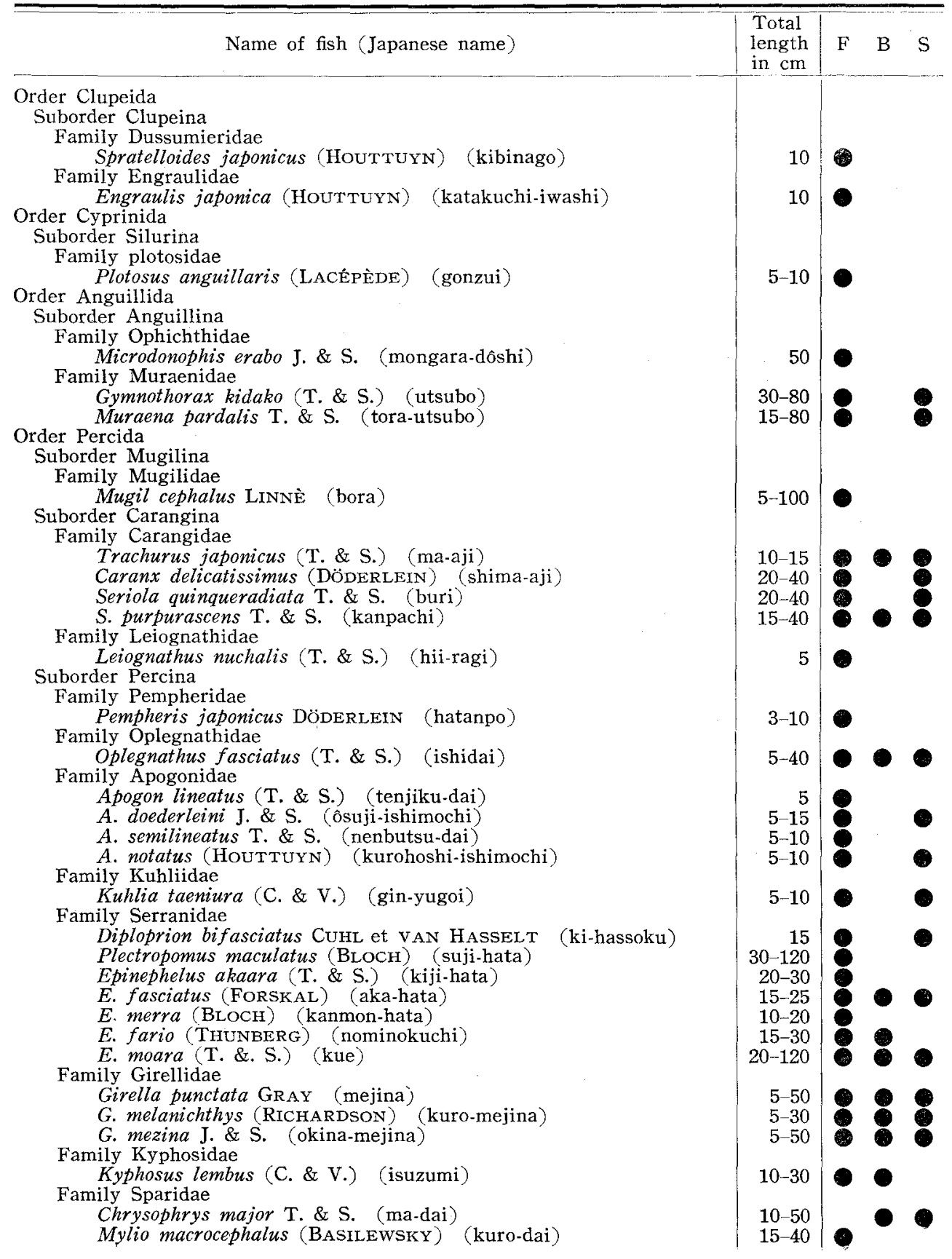


Table 1. (Continued)

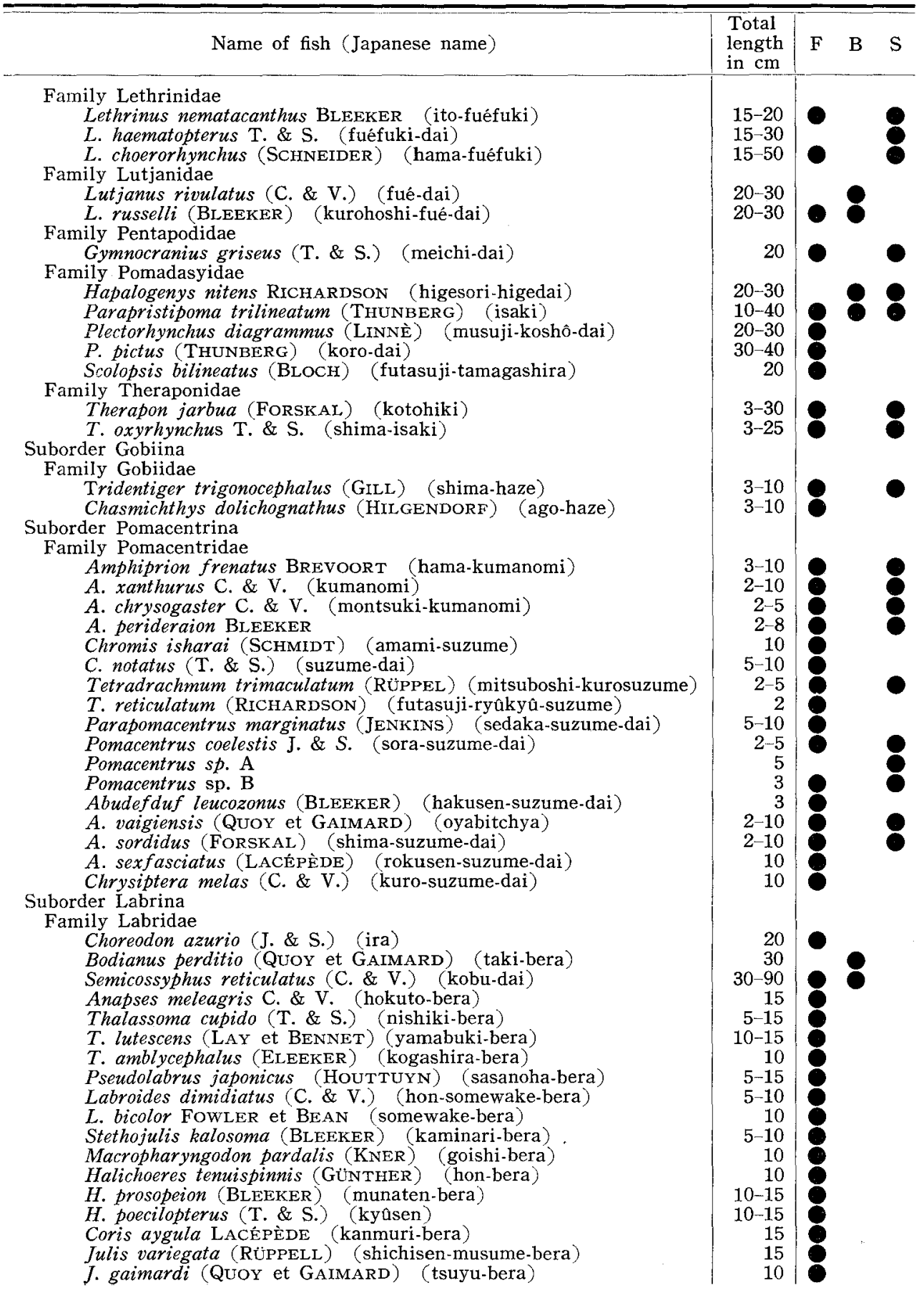


Table 1. (Continued)

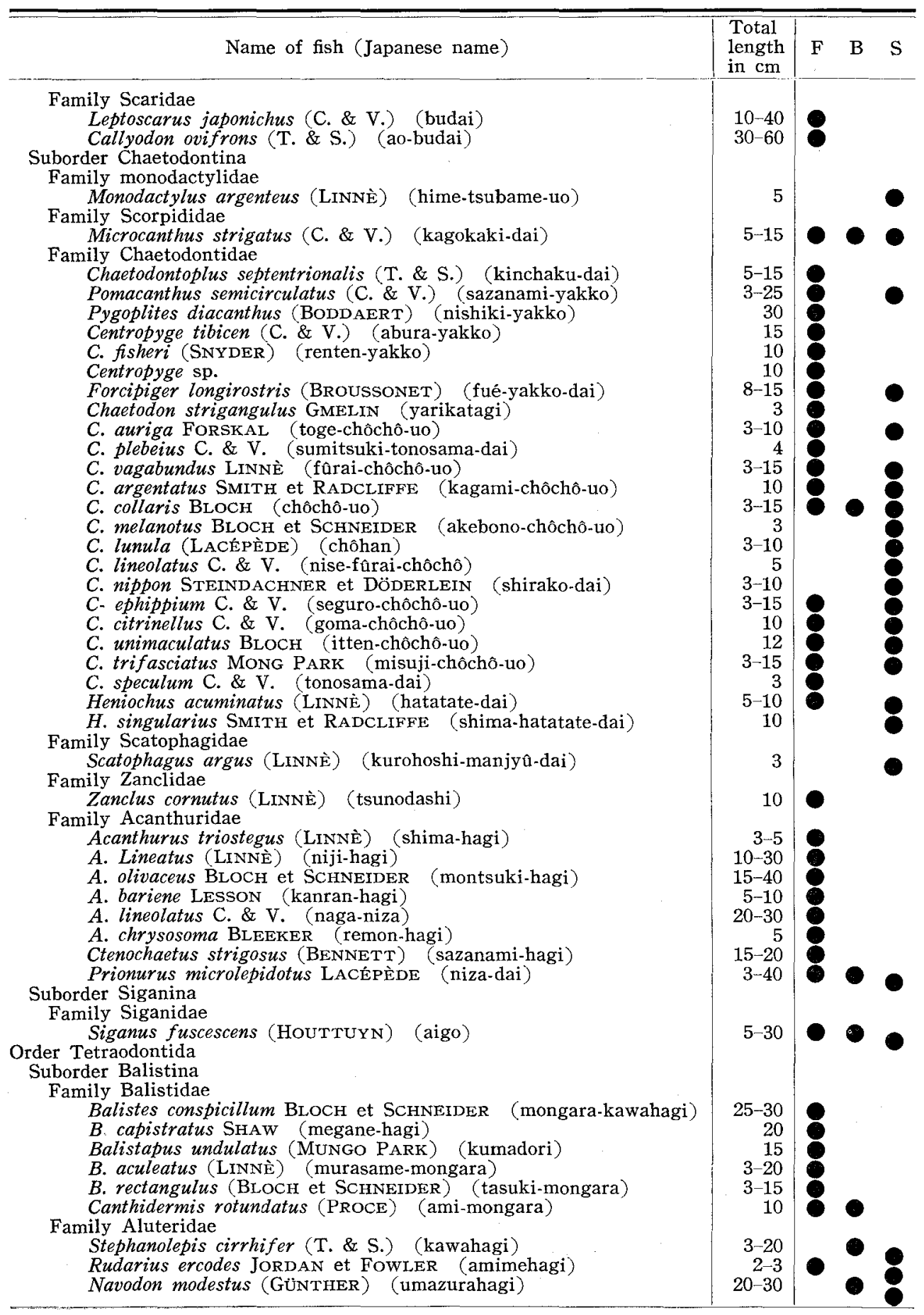


observed in the small tank.

Most of the data of field observations were gained during the collecting trips of the Suma Aquarium mostly made by myself with the aid of some of my colleagues in the years 1958-1962. The observations in various kinds of tanks were made wholly at the Suma Aquarium.

(1) Field surveys

Data concerning the behaviors in the natural habitat were accumulated during the 26 surveys shown in Table 2.

Table 2. List of surveys.

\begin{tabular}{|c|c|c|}
\hline \multicolumn{3}{|c|}{ Tanabe Bay, Wakayama Prefecture } \\
\hline $\begin{array}{l}1955 \\
1956 \\
1958 \\
1959 \\
1960 \\
1961 \\
1962\end{array}$ & $\begin{array}{l}\text { June, July, August, September, } \\
\text { August, September, Octover } \\
\text { August, Octover } \\
\text { August, Octover } \\
\text { July, August, Octover } \\
\text { July, August, August, Octover } \\
\text { June, September }\end{array}$ & Octover \\
\hline \multicolumn{3}{|c|}{ Ankyaba, the Amami Islands, Kagoshima Prefecture } \\
\hline $\begin{array}{l}1961 \\
1962\end{array}$ & $\begin{array}{l}\text { May } \\
\text { July }\end{array}$ & \\
\hline \multicolumn{3}{|c|}{ Shiono-misaki, Wakayama Prefecture } \\
\hline 1960 & July & \\
\hline \multicolumn{3}{|c|}{ Kasaoka Bay, Seto Inland Sea } \\
\hline $1954-55$ & about 20 times & \\
\hline \multicolumn{3}{|c|}{ Osaka Bay, Seto Inland Sea } \\
\hline $1958-62$ & many & \\
\hline
\end{tabular}

Twenty-one surveys were made in Tanabe Bay on the southwest coast of Kii Peninsula and two in the vicinity of Ankyaba, the Amami Islands, situted between kŷ̂syû Island and Okinawa (Fig. 1).

The dives in Osaka Bay and Kasaoka Bay were made only for the supplemental purpose, since there the lower transparency of sea water hinders the accurate observations.

Diving stations in Tanabe Bay: In Tanabe Bay rocky shores are developed particularly on the southwest coast of the bay and at small islets, besides a number of rocky reefs are scattered here and there in and out of the bay.

Oceanographic conditions, tidal currents, plankton, benthos, intertidal animal 


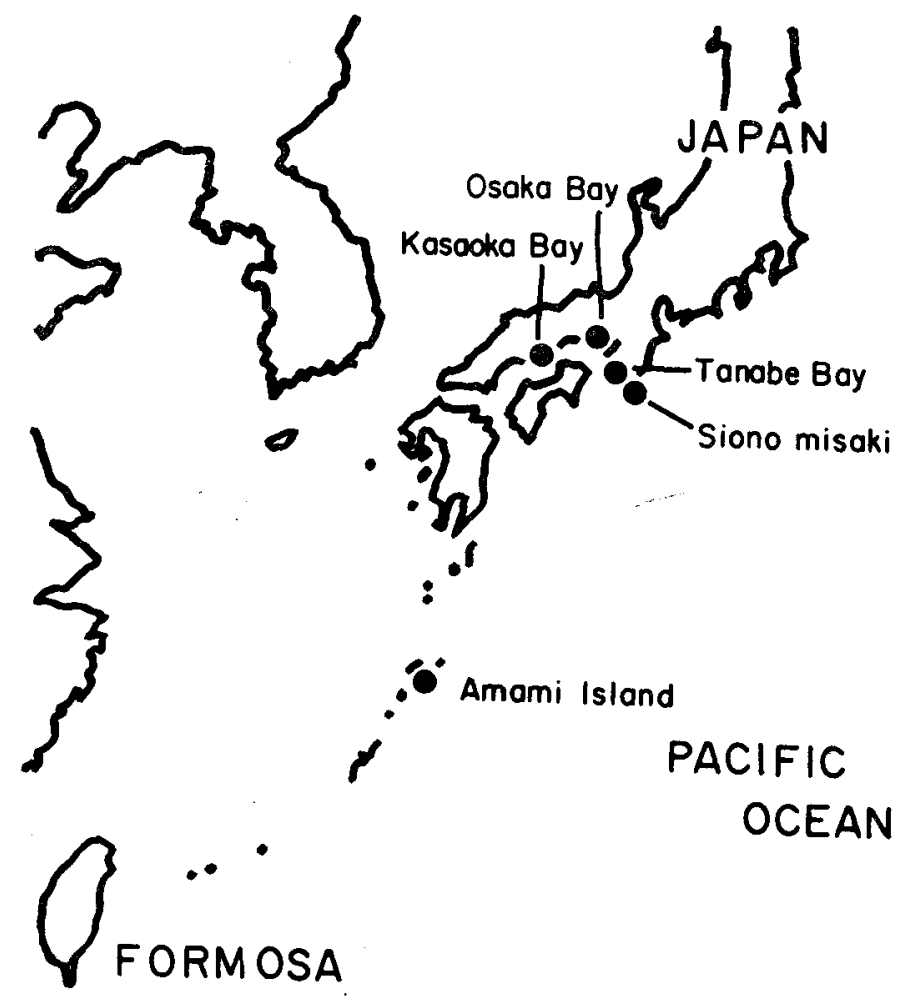

Text-fig. 1. Situations of surveyed areas.

communities and coastal fish distributions of the bay have already been investigated and reported by MIYADI, HAYAMI and others (1958). The details of the collecting trips of the Suma Aqarium to this bay have already been published, too (Collecting Party of Suma Aquarium, 1962).

The actual diving localities are shown in Fig. 2.

Diving stations at Ankyaba, the Amami Islands: Rocky shores and small coral reefs are developed everywhere along the coasts of these islands. Many species of wrasses, butterfly fishes, surgeon fishes and damsel fishes inhabited numerously around the rocky reefs and among corals. Diving stations are shown in Fig. 3.

Other stations for supplemental divings: The diving stations in Kasaoka Bay are already described by Fuse (1962 a, b) and HARADA (1962) in detail and the data obtained are partly in the present paper. Supplemental diving observations were also made in the sea backward the Suma Aquarium and off Iwaya, the north end of Awaji Island.

Informations offered by fishermen: Informations on the habits of some fishes 


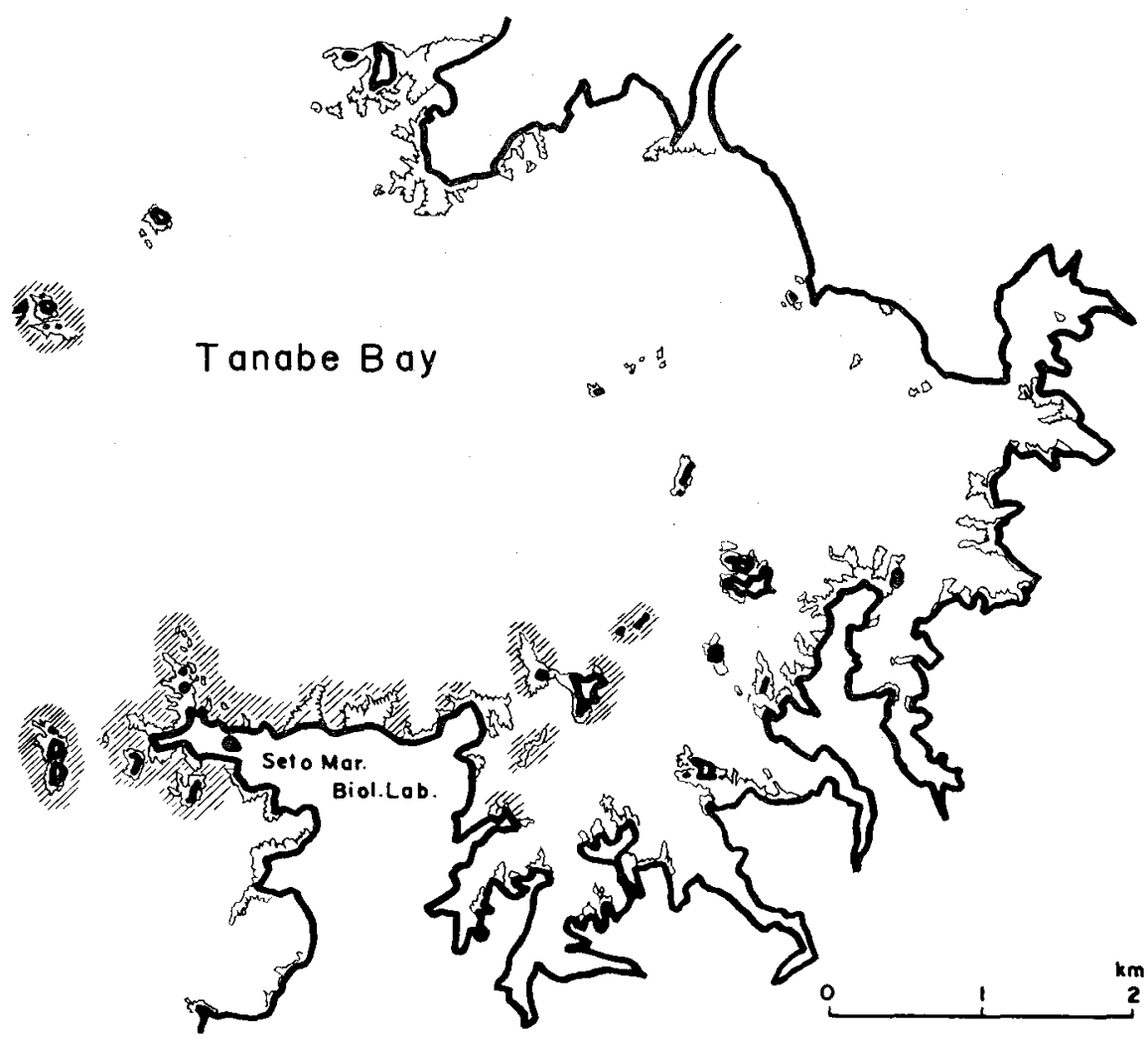

Text-fig. 2. Diving stations in Tanabe Bay.

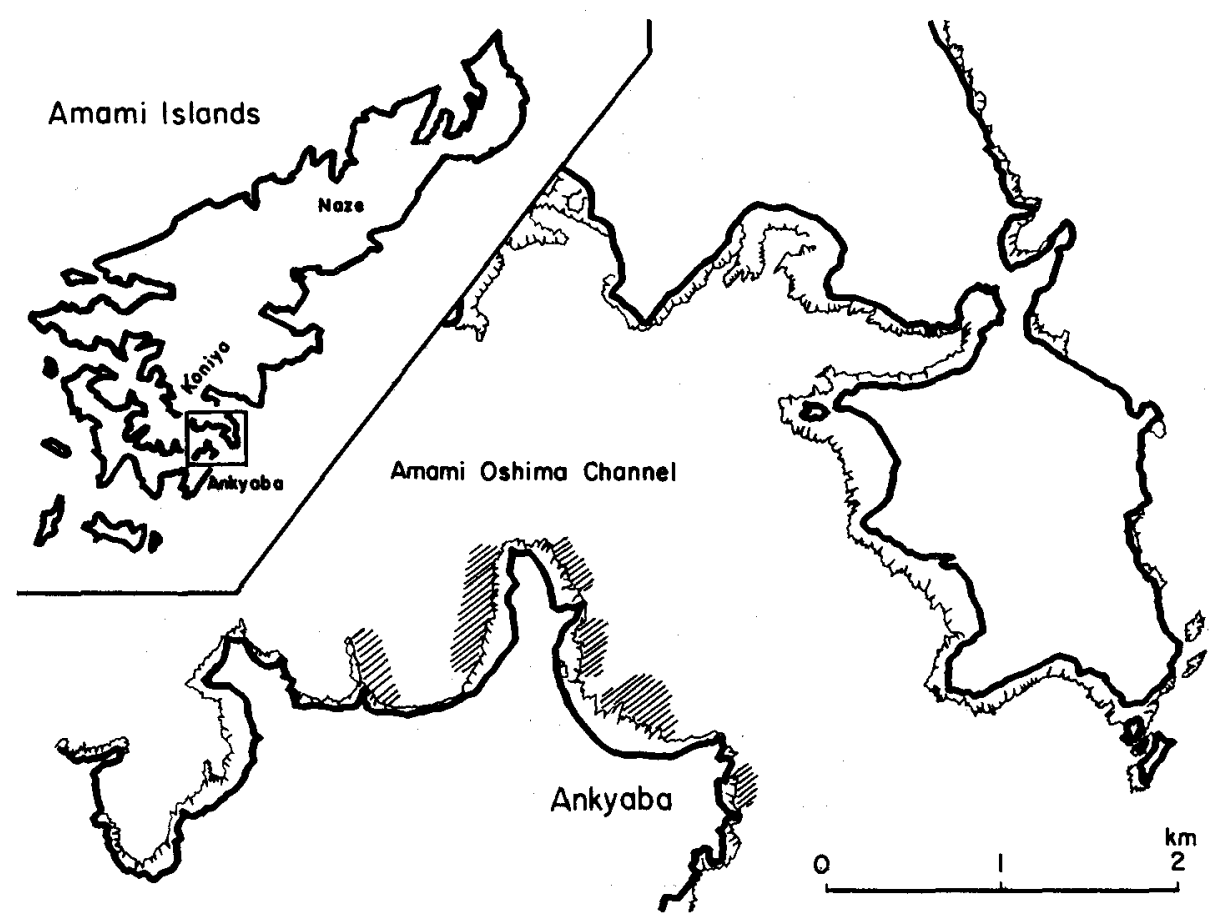

Text-fig. 3. Diving stations at Ankyaba, the Amami Islands. 
inaccessible to me were gathered from fishermen and used as data for discussion after close selection. Especially I appreciate those offered by Mr. IwAKI, a skillful fisherman in Shirahama, since they gave me sometimes important clues and precise knowledge on the behaviors of fishes in Tanabe Bay.

(2) Tanks used for experiments

Seven types of tanks of the Suma Aquarium were used for observations of the behaviors of captured fishes (Table 3).

Table 3. Seven types of tanks used for observations.

\begin{tabular}{l|rr|l}
\hline & Size & Volume & \\
\hline Big tank & $19 \times 7 \times 2.7 \mathrm{~m}$ & $350 \mathrm{~m}^{3}$ & Exhibition tank \\
Tank A & $170 \times 110 \times 100 \mathrm{~cm}$ & $1.9 \mathrm{~m}^{3}$ & Exhibition tank \\
Tank B & $110 \times 90 \times 100 \mathrm{~cm}$ & $1 \mathrm{~m}^{3}$ & Exhibition tank \\
Tank C & $80 \times 45 \times 45 \mathrm{~cm}$ & $0.16 \mathrm{~m}^{3}$ & Exhibition tank \\
Tank D & $80 \times 45 \times 45 \mathrm{~cm}$ & $0.16 \mathrm{~m}^{3}$ & Fish reserve tank \\
Tank E & $100 \times 40 \times 25 \mathrm{~cm}$ & $100 l$ & Fish reserve tank \\
Tank F & $50 \times 40 \times 25 \mathrm{~cm}$ & $50 l$ & Fish reserve tank \\
\hline
\end{tabular}

The big tank: It is eliptical in shape and $19 \mathrm{~m}$ long, $7 \mathrm{~m}$ wide and $2.7 \mathrm{~m}$ deep (Fig. 4). A small rocky reef of complicated shape is built on the bottom and ten windows with panes of thick glass, $150 \mathrm{~cm} \times 100 \mathrm{~cm}$ in size and $3 \mathrm{~cm}$ in thickness, allow the observations from outside. The sea water in this tank is
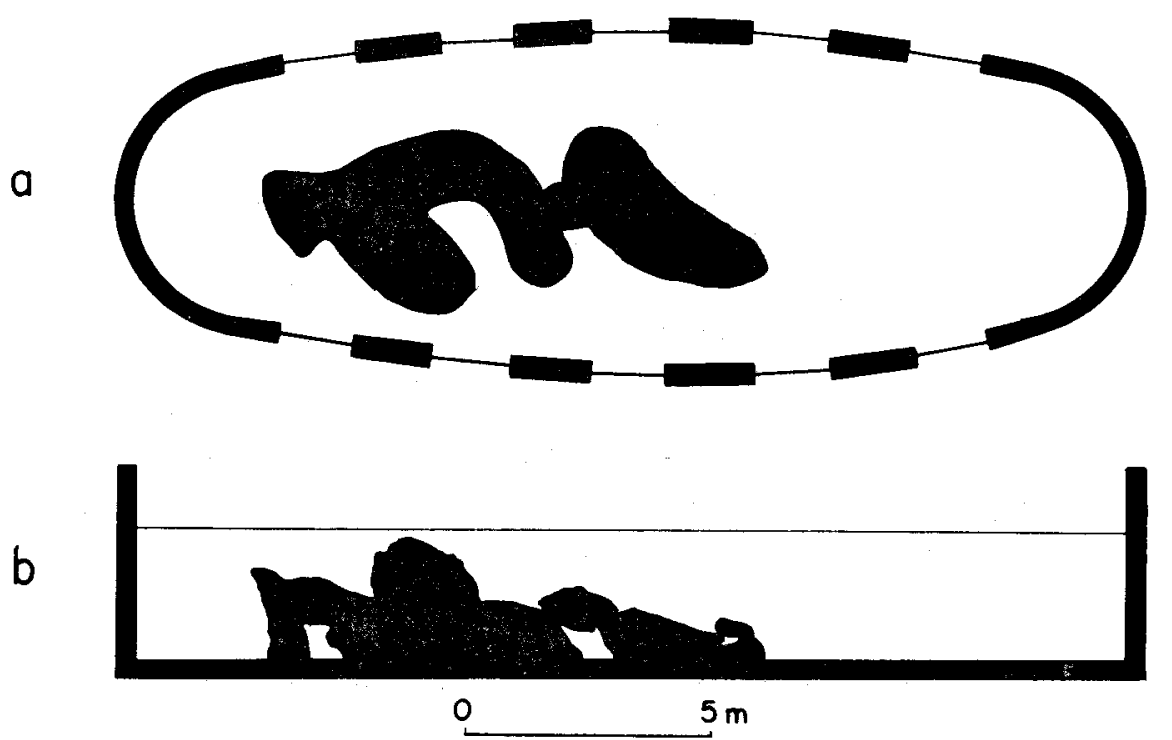

Text-fig. 4. The plane figure (a) and the section along the longitudinal diameter (b) of the big tank. 
circulated by two $3 \mathrm{HP}$ pumps flowing through two sand filters of the total area of $15 \mathrm{~m}^{2}$ on the way. Thus the continuous filtering maintains a high transparency so that observations can be made very easily with high accuracy. Water temperature fluctuates from $6^{\circ} \mathrm{C}$ in February to $28^{\circ} \mathrm{C}$ in August as shown in Fig. 5.

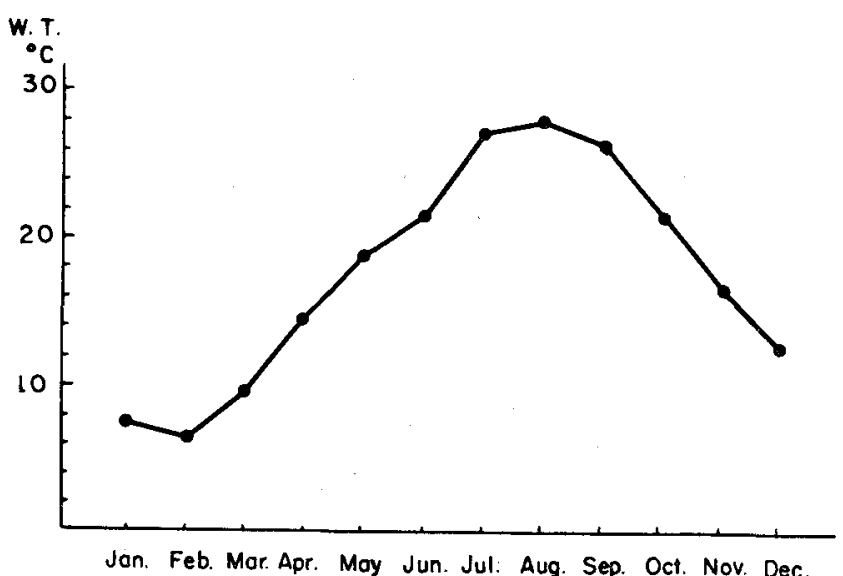

Text-fig. 5. Fluctuations of water temperature in the big tank in 1961. Temperatures are shown as monthly averages.

In this tank many fishes such as sharks and rays (Triakis scyllia, Mustelus griseus, Dasyatis akajei etc.), oceanic teleosts (Seriola quinqueradiata, S. purpurascens, etc.), large rocky reef fishes (Epinephelus moara, Semicossyphus reticulatus, etc.) and many other coastal or rocky reef fishes are reared from spring to autumn.

Small tanks: The main building of the Suma Aquarium has 5 pools, 23 show tanks and 7 table tanks. The show tanks are arranged along the wall of exhibition halls, while the pools are built on the floor. Table tanks are made of iron frame and glass panes on four sides. The sea water of about $150 \mathrm{~m}^{3}$ is flowing through these pools and tanks being pumped by a $10 \mathrm{HP}$ motor through four sand filters of the total area of $40 \mathrm{~m}^{2}$ on the way.

The water is warmed in winter and cooled in summer to keep the water temperature at $20^{\circ} \mathrm{C}$ from autumn to spring and at $23^{\circ} \mathrm{C}$ in summer. Table tanks (D, E and F in Table 2) are used for studying some behaviors of small fishes and the water is shared from the above-mentioned circular system.

\section{Social Behaviors in Natural Habitat}

Four Behavior Types of Marine Fishes

Results of the underwater observations seem to clear out some principles 
of the social behaviors of fishes. Marine fishes have respectively their own unique mode of behaviors in natural habitats and it is very possible that these modes of behaviors are classified into much less types of behavior.

There are two categories of fish movement: hovering and residing. On the other hand, there are also two categories of fish grouping: aggregating and solitary. And all the behavior modes of fishes are to be classified into next four behavior types ; 1) aggregating and hovering, 2) aggregating and residing, 3) solitary and hovering, and 4) solitary and residing.

Aggregating and hovering fishes are nothing but "schooling fishes". BREDER and HALPERN (1946) and BREDER (1959) defined the fish school as "..... in which all individuals are orientated in a common direction, regularly spaced, and moving at a uniform speed".

Residing and aggregating type means a state in which fishes are aggregating at a certain limited place without being orientated in a common direction and not resting: to this state I proposed the term "assemblage" previously (Okuno, 1956 a and 1963).

Fishes of solitary and hovering type have not any definite "home" but always are hovering about alone, while those of solitary and residing type have respectively their own shelter or refuge and always staying there or thereabout.

The 117 species of fishes studied belong respectively to one of the abovementioned behavior types as shown in Table 4 .

\section{Descriptions of Social Behaviors of some Fishes}

Social behaviors of 74 species of fishes in their natural habitats are descrived below in order to be compared with those shown in captivity.

Family Muraenidae (moray eels)

Gymnothorax kidako (nom. Japan., utsubo)

Muraena pardalis (tora-utsubo)

G. kidako is abundant in Tanabe Bay and met with almost always during divings, while $M$. pardalis is rather fewer. They live solitarily under rocky ledges or in caves, but any territorial behavior has never been observed as far as my underwater observations are concerned. Sometimes, several individuals of G. kidako were found lurking together under the same ledge. I had chances to observe three or four more unidentified species of moray eels and found that their habits were similar to those of G. kidako and M. pardalis. Hratr and Strasbrug (1960) also observed similar behaviors on 15 species of this family on the coral reefs of the Marshall Islands.

Family Carangidae

Trachurus japonicus (nom. Japan., ma-aji) 
Table 4. Social behaviors of marine fishes in their natural habitats.

Stable school. $\odot$ Relatively stable school. $\bigcirc$ Unstable school.

\begin{tabular}{|c|c|c|c|c|}
\hline & \multicolumn{2}{|c|}{ Grouping } & \multicolumn{2}{|c|}{ Solitary } \\
\hline - & $\begin{array}{c}\text { Hovering } \\
\text { (school) }\end{array}$ & $\begin{array}{l}\text { Residing } \\
\text { (assemblage) }\end{array}$ & Hovering & Residing \\
\hline $\begin{array}{l}\text { Family Dussumieridae } \\
\text { Spratelloides japonicus }\end{array}$ & & & & \\
\hline $\begin{array}{l}\text { Family Engraulidae } \\
\text { Engraulis japonica }\end{array}$ & & & & \\
\hline $\begin{array}{l}\text { Family Plotosidae } \\
\text { Plotosus anguillaris }\end{array}$ & & & & \\
\hline $\begin{array}{l}\text { Family Ophichthidae } \\
\text { Microdonophis erabo }\end{array}$ & & & & \\
\hline $\begin{array}{c}\text { Family Muraenidae } \\
\text { Gymnothorax kidako } \\
\text { Muraena pardalis }\end{array}$ & & & & \\
\hline $\begin{array}{l}\text { Family Mugilidae } \\
\text { Mugil cephalus }\end{array}$ & & & & \\
\hline $\begin{array}{l}\text { Family Carangidae } \\
\text { Trachurus japonicus } \\
\text { Caranx delicatissimus } \\
\text { Seriola quinqueradiata } \\
\text { S. purpurascens }\end{array}$ & & & & \\
\hline $\begin{array}{l}\text { Family Leiognathidae } \\
\text { Leiognathus nuchalis }\end{array}$ & 0 & & & \\
\hline $\begin{array}{l}\text { Family Pempheridae } \\
\text { Pempheris japonicus }\end{array}$ & 0 & & & \\
\hline $\begin{array}{l}\text { Family Oplegnathidae } \\
\text { Oplegnathus fasciatus }\end{array}$ & $\bullet$ & & & \\
\hline $\begin{array}{l}\text { Family Apogonidae } \\
\text { Apogon lineatus } \\
\text { A. doederleini } \\
\text { A. semilineatus } \\
\text { A. notatus }\end{array}$ & $\stackrel{\ominus}{\ominus}$ & & & \\
\hline $\begin{array}{l}\text { Family Kuhliidae } \\
\text { Kuhlia taeniura }\end{array}$ & 0 & & & \\
\hline $\begin{array}{l}\text { Family Serranidae } \\
\text { Plectropomus maculatus } \\
\text { Epinephelus akaara } \\
\text { E. fasciatus } \\
\text { E. merra } \\
\text { E. fario } \\
\text { E. moara }\end{array}$ & & & & \\
\hline $\begin{array}{l}\text { Family Girellidae } \\
\text { Girella punctata } \\
\text { G. melanichthys } \\
\text { G. mezina }\end{array}$ & 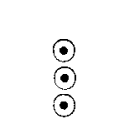 & & & \\
\hline $\begin{array}{l}\text { Family Kyphosidae } \\
\text { Kyphosus lembus }\end{array}$ & $\odot$ & & & \\
\hline $\begin{array}{l}\text { Family Sparidae } \\
\text { Chrysophrys major } \\
\text { Mylio macrocephalus }\end{array}$ & $\bigodot$ & & & \\
\hline $\begin{array}{l}\text { Family Lethrinidae } \\
\text { Lethrinus nematacanthus } \\
\text { L. haematopterus } \\
\text { L. choerorhynchus }\end{array}$ & $(\odot)$ & & & \\
\hline
\end{tabular}


Table 4. (Continued)

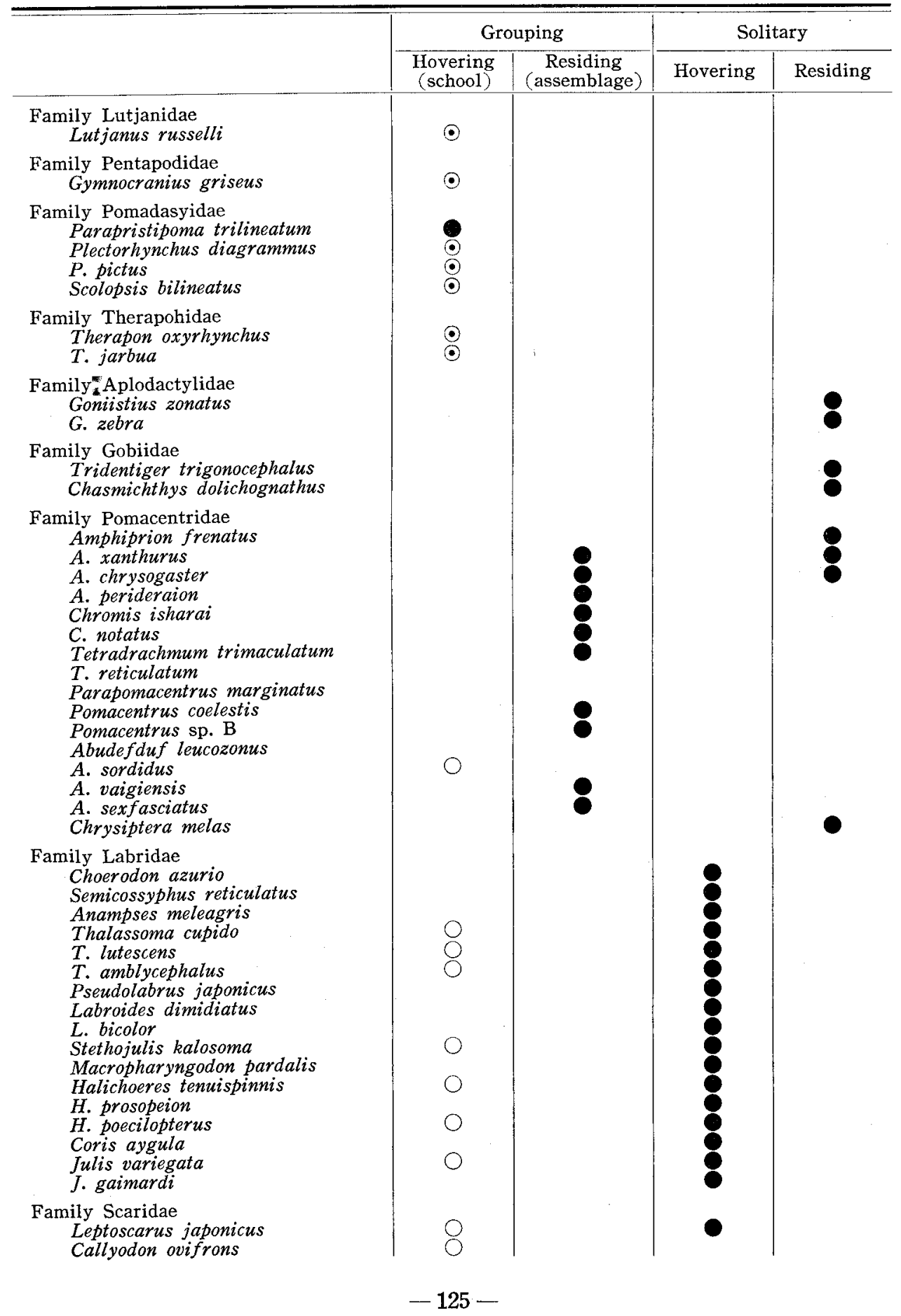


Table 4. (Continued)

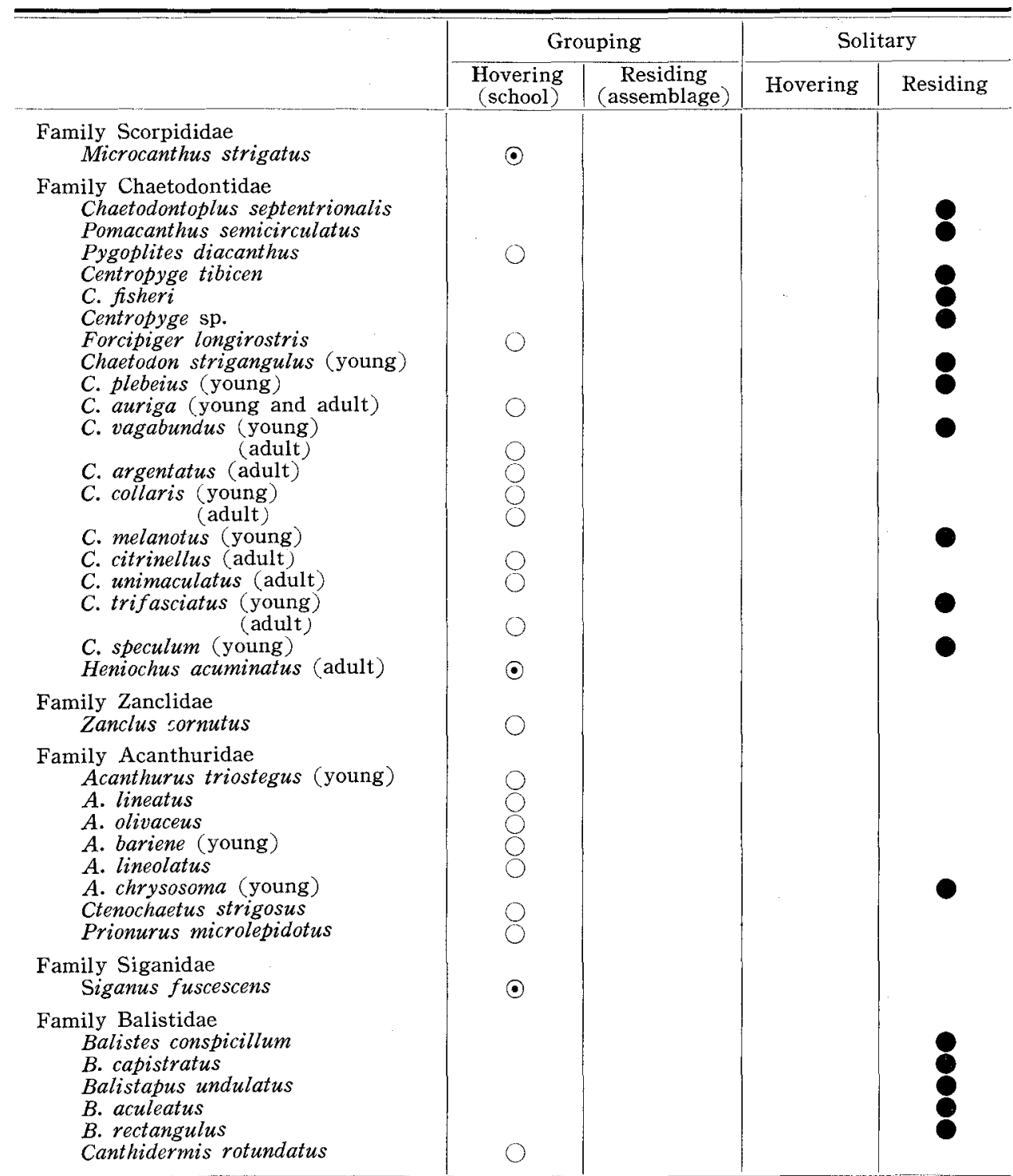


Caranx delicatissimus (shima-aji)

Seriola quinqueradiata (buri)

S. purpurascens (kanpachi)

All of these fishes have the stable schooling habit. Schools of S. purpurascens consisting each of 20-30 individuals were occasionaly observed cruising in the mid-layer along the shore of Tanabe Bay, although large schools consisting of 300 to 500 individuals were met with only rarely. They form compact schools and swim rapidly without break or separation of schools. Similar schooling behavior has been observed in S. quinqueradiata. Schools of C. delicatissimus consisting of 20-30 to 500-600 individuals have been met with in Tanabe Bay in the mid-layer or near the sandy bottom. Large schools of $T$. japonicus were observed occasionally in the shallow waters, they seemed as being rather unstable than in S. purpurascens and C. delicatissimus since the distance between individuals was relatively large and separation of school sometimes occurred.

It is supposed that the carangid fishes form generally stable schools of various sizes, most frequently of very large size, and are migrating in the midlayer. Hiatt and Strasburg (1960) observed in the waters of the Marshall Islands the schooling behavior of six species of this family and state that they show more or less the schooling habit and that they are rapid-swimming, or in some species slow-cruising, roving carnivores.

Family Oplegnathidae

Oplegnathus fasciatus (nom. Japan., ishi-dai)

Small schools of young $O$. fasciatus were often met with in Osaka Bay, these schools seemed relatively unstable. Generally they do not swim actively, sometimes staying near the rock cliff. Adult fishes also were observed in schools each consisting of five to ten fishes, although solitary individuals were seen occasionally.

Family Apogonidae (cardinal fishes)

Apogon lineatus (nom. Japan., tenjiku-dai)

A. doederleini (ôsuji-ishimochi)

A. semilineatus (nenbutsu-dai)

A. notatus (kurohoshi-ishimochi)

These fishes are nocturnal and show a schooling habit. For instance, $A$. notatus is aggregated in large numbers under the projecting rocks or in the crevices in daytime, while in the evening they migrate to the offshore water in schools. Similar behaviors were also observed on A. doederleini and A. semilineatus. In Kasaoka Bay $A$. lineatus occurs on the muddy flat in daytime, but moves to the Zostera belt at night in schools; this was ascertained by a series of samplings made in the Zostera belt in the years 1953-55 (Fuse, 1962 a). Schools of these fishes are, however, not so stable as those of carangid fishes. 
Hratt and Strasburg (1960) record the observations on six species of Apogon occurring solitarily or rather in small schools, but stating "some species not covered in this study form dense school".

Family Kuhliidae

Kuhlia taeniura (nom. Japan., gin-yugoi)

This fish occurs usually in small schools consisting of three to ten individuals in tide pools or crevices and hovers near the water surface within a certain area.

Family Serranidae (groupers)

Plectropomus maculatus (nom. Japan., sujihata)

Epinephelus akaara (kijihata)

E. fasciatus (akahata)

E. fario (nominokuchi)

E. moara (kue)

E. merra (kanmonhata)

All of these groupers occur solitarily. E. akaara was found inhabiting among rocks in Kasaoka Bay, E. fario and E. fasciatus living under the ledges of rocks or among corals in Tanabe Bay, and E. merra hiding itself in caves under coral reefs in the coastal waters of the Amami Islands. It was observed that a $1.2 \mathrm{~m}$ long individual of $P$. maculatus and three large individuals of $E$. moara respectively $1.2,1$ and $0.7 \mathrm{~m}$ in estimated total length were each occupying its own refuge which is a small but deep cave, and the fishes always retreat to their own refuges whenever they were chased by the observer.

Family Girellidae

Girella punctata (nom. Japan., mejina)

G. melanichthys (kuromejina)

G. mezina (okinamejina)

General behaviors, including the schooling habit, of $G$. punctata and $G$. melanichthys in Tanabe Bay have already been reported in my previous paper in detail (OKuno, $1962 \mathrm{~b}$ ). Their adults form rather unstable schools, while their youngers often form together common schools perfectly mixed.

G. mezina is rather rare along the coast of Japan. Young individuals of this species were found sometimes strayed into the schools formed by young fishes of the preceding two species or occurred in tide pools in small schools in Tanabe Bay. Schools of three or four adult individuals with about $50 \mathrm{~cm}$ total length were met with at the rocky shore of the Amami Islands.

Family Kyphosidae

Kyphosus lembus (nom. Japan., isuzumi)

This fish occurs in small schools consisting each of two to ten individuals in the area along the coast of Tanabe Bay in the summer season. But, the 
informations from fishermen tells that the fishes are aggregating in large schools of several hundred individuals and staying close to the rocky shore to take the newly growing seaweeds in winter.

Family Lethrinidae (snappers)

Lethrinus choerorhynchus (nom. Japan., hama-fuefuki)

L. nematacanthus (ito-fuéfuki)

Schools of $L$. choerorhynchus are usually not so large in summer, consisting of only two to five individuals and generally hovering about from reef to reef without staying in any limited area. It is said by fishermen that the fish forms relatively large schools in autumn and leaves the rocky shore. According to the informations from fishermen, L. haematopterus seems to have nearly the same behavior as $L$. choerorhynchus.

However, my data of underwater observations seem to show that at least in summer L. nematacanthus lives solitarily in the rocky reef area, although it is not certain whether respective individual is settled at any limited place or not.

Hiatt and Strasburg (1960) reported a species of this genus, L. microdon, occurs in solitary, but without any comments about whether it is staying or cruising.

Family Lutjanidae (snapper)

Lutjanus russelli (nom. Japan., kurohoshi-fuédai)

L. russelli was found visiting the rocky shore frequently in small schools of two to five individuals in Tanabe Bay and always cruising around, but not staying at any limited place. On coral reefs of the Marshall Islands, other five species of the same genus were found forming small or large schools. Some of these fishes are known to have a hovering habit (HiATt and STRASBURG, 1960).

Family Pentapodidae

Gymnocranius griseus (nom. Japan., meichi-dai)

I had only a chance to observe a school of G. griseus in Tanabe Bay consisting of 17 individuals and slowly swimming over the rocky flat. HiATT and Strasburg (1960) also observed the same species in the waters around the Marshall Islands, mentioning "it is seen in groups of two or three individuals hovering around large coral mound". It may be safely accepted that schools of this fish is not so large and that the fish is a slow-swimming, hovering one.

Family Pomadasyidae

Parapristipoma trilineatum (nom. Japan., isaki)

$P$. trilineatum occurs in Tanabe Bay in schools very stable and large, sometimes containing several hundreds of individuals. Usually the fish is resting in daytime, aggregating in the shade of rocks or along the rocky cliffs and without any active movement. Fishermen's informations allude that the 
fish cruises away to the offshore area at night.

Family Pomacentridae (damsel fishes)

Subfamily Amphiprioninae

Amphiprion frenatus (nom. Japan., hama-kumanomi)

A. xanthurus (kumanomi)

A. chrysogaster (montsuki-kumanomi)

A. perideraion

These crown fishes are usually living in a close relationship with big sea anemones, most frequently with Parasicyonis actinostoloides WASSILIEFF, and the relation between these two animals is said to be the mutual symbiosis (GoHar, 1948, Davenport and Norris, 1958 and OKuno and Aokr, 1959) or mutualism (MAnsuetr, 1963). A. xanthurus has been found living solitarily occupying own sea anemone in Tanabe Bay, but in one case eight individuals were found living together in the same sea anemone. In the coastal waters of the Amami Islands, on the other hand, this fish was found almost always in pairs in respective sea anemone in May and July. A. chrysogaster in Tanabe Bay and $A$. perideraion in the coastal waters of the Amami Islands occur usually in groups of two to five individuals in each sea anemone. A. frenatus was found solitarily in respective sea anemone in the waters of the Amami Islands.

Subfamilies Chrominae, Pomacentrinae and Glyphisodontinae

Chromis isharai (nom. Japan., amami-suzume)

C. notatus (suzume-dai)

Tetradrachmum trimaculatum (mitsuboshi-kuro-suzume)

T. reticulatum (futasuji-ryûkyû-suzume)

Parapomacentrus marginatus (sedaka-suzume-dai)

Pomacentrus coelestis (sora-suzume-dai)

Pomacentrus sp. B

Abudefduf leucozonus (hakusen-suzume-dai)

A. sordidus (shima-suzume-dai)

A. vaigiensis (oyabitchya)

A. sexfasciatus (rokusen-suzume-dai)

Chrysiptera melas (kuro-suzume-dai)

$T$. trimaculatum occurs mostly near big sea anemone solitarily or in small groups of two or three individuals in Tanabe Bay, but a few individuals are found among the branches of acroporan corals. Only a single specimen of $T$. reticulatum was observed in Tanabe Bay being associated with an acroporan coral (ARaga, 1963). Hiatt and Strasburg (1960) also observed in the waters of the Marshall Islands that Dascyllus (= Tetradrachmum) aruanus aggregated in large numbers among the branches of ceratiform corals. Thus it may be said safely that the fishes of the genus Tetradrachmum live solitarily or in aggregation being associated with sea anemones or branching corals. 
Parapomacentrus marginatus has a territorial habit as already reported (OkUno, 1956 a) to defend his area from the fishes of any other species. Abudefduf leucozonus is also a solitary and territorial fish and usually found in tide pools. It is reported by Hratr and Strasburg (1960) that Pomacentrus nigricans also exhibits a very strong territorial tendency in the coral reef areas of the Marshall Islands. Chrysiptera melas occurs solitarily in many cases, but any territorial behavior has not been observed. C. isharai and A. sexfasciatus in the coastal waters of the Amami Islands, $C$. notatus, Pomacentrus coelestis and $A$. vaigiensis in Tanabe Bay, were observed in small or large groups. C. isharai and $C$. notatus are crowded in the middle layer, while Pomacentrus coelestis and A. sexfasciatus are aggregated near the bottom. Pomacentrus $\mathrm{sp}$. B occurs usually in solitary but sometimes in small groups of two to five individuals on or among the rubbles.

On the social behaviors of pomacentrid fishes of the Marshallese coral reefs, Hiatt and Strasburg (1960) state that "many are solitary, some form small aggregations, while other occur in dence aggregations ....." and "almost all of them, particularly the aggregating species, are closely associated with, even ecologically bound to, giant heads of branching corals".

My observations coincide with their's but Abudefduf sordidus. This fish is the only species of the observed 15 species of the family Pomacentridae, that is known to form schools. It is found occasionally in small schools of two to five individuals in tide pools or the innermost parts of rocky chasms or crevices, it is never bound to any refuge but hovering in limited areas not so large as in other schooling fishes.

Summarizing the above-mentioned descriptions the general characteristics of aggregations of pomacentrid or damsel fishes may be noted in:1) being associated with some limited places such as branching corals or rock rubbles, 2) not resting but actively moving or feeding and 3) keeping the individual movement independent one another, in other words without any uniformity of behaviors in component fishes which is shown in normal fish schools. However, these characteristics can not be seen in the resting aggregations of schooling fishes such as Parapristipoma trilineatum and Apogon notatus. For this reason I want to propose the term "assemblage" for the aggregations of pomacentrid fishes in order to distinguish them from the resting aggregations of other schooling fishes (OKuno, 1956 a).

Family Scorpididae

Microcanthus strigatus (nom. Japan., kagokaki-dai)

This fish occurs in small schools of two to ten individuals along the rocky shores in Tanabe Bay, hovering within a certain area.

Family Chaetodontidae

Subfamily Pomacanthinae (angel fishes) 
Chaetodontoplus septentrionalis (nom. Japan., kinchaku-dai) young

Pomacanthus semicirculatus (sazanami-yakko) young and adult

Pygoplites diacanthus (nishiki-yakko) adult

Centropyge tibicen (abura-yakko) subadult

C. fisheri (renten-yakko) subadult

Subfamily Chaetodontinae

Forcipiger longirostris (nom. Japan., fué-yakko-dai) adult

Chaetodon strigangulus (yarikatagi) young

C. plebeius (sumitsuki-tonosama-dai) young

C. auriga (toge-chôchô-uo) young and adult

C. vagabundus (fûrai-chôchô-uo) young and adult

C. argentatus (kagami-chôchô-uo) adult

C. collaris (chôchô-uo) young and adult

C. melanotus (akebono-chôchô-uo) young

C. lunula (chôhan) adult

C. citrinellus (goma-chôchô-uo) adult

C. unimaculatus (itten-chôchô-uo) adult

C. trifasciatus (misuji-chôchô-uo) young and adult

C. speculum (tonosama-dai) young

Heniochus acuminatus (hatatate-dai) adult

Pomacanthus semicirculatus, one of the angel fishes, occurs in solitary and has a regular refuge for which the rocky cave is used in many case as reported already (Okuno, Kurio and Nishiguchi, 1960). Again in the coastal waters of the Amami Islands I observed that adult fishes had the shelters among coral reefs (OKuno, Nishiguchi and Kurto, 1962). Other four angel fishes, Chaetodontoplus septentrionalis and Centropyge fisheri in Tanabe Bay and Centropyge tibicen and Centropyge sp. in the waters of the Amami Islands, show the habits similar to that of Pomacanthus semicirculatus. HratT and Strasburg (1960) also mention that Centropyge flavissimus is common around the living corals, usually hiding itself in crevices or holes in the coral reefs areas of the Marshall Islands. On the other hand, the behaviors of Pygoplites diacanthus observed in the waters of the Amami Islands seem rather to be exceptional much differing from those of other six species of angel fishes observed, as it was never found staying at any refuge but always hovering in the middle layer solitarily or sometimes in small schools.

Most of butterfly fishes occurs in pair or solitarily and without any regular shelter. In the coastal waters of the Amami Islands, most of adult individuals of $F$. longirostris, Chaetodon argentatus, C. citrinellus, $C$. unimaculatus and $C$. trifasciatus occurred in pair at least in May and July and hovering among corals without staying at any shelter. In Tanabe Bay, adults of Chaetoden auriga and C. collaris occur generally in solitary or sometimes in small schools of two to three individuals, but without any regular shelter. H. acuminatus forms the 
school of two to ten individuals in usual and thus this species may be accepted as one of the species with the most extensive schooling tendency among butterfly fishes.

On the other hand, most of youngers of butterfly fishes occur usually among the branches of ceratiform corals in solitary or in aggregation of two to five individuals. For instance, the life in young Chaetodon strigangulus, C. plebeius, C. melanotus, C. trifasciatus and C. speculum is associated with small branching corals in Tanabe Bay, while the young $C$. auriga, C. collaris and C. vagabundus sometimes occur on the rocky or sandy flats without having any clearly defined shelter against the previously mentioned five species.

Hiatt and Strasburg (1960) mention that Megaprotodon (=Chaetodon) strigangulus and Chaetodon reticulatus are staying very close to living corals or hiding themselves in crevices or holes, while $C$. lunula, C. citrinelus, $C$. ephippium, C. vagabundus and C. auriga occur solitarily or in pairs around corals among reefs and that the last one sometimes is found swimming over sandy areas. These observations agree in general with mine.

Thus, the social behaviors of angel and butterfly fishes may be summarized as: 1) solitary and with well-defined refuge (angel fishes, except for Pygoplites diacanthus), 2) solitary or aggregating and being associated with living corals (young specimens of butterfly fishes, excepting Chaetodon auriga, C. vagabundus and $C$. collaris), and 3) hovering solitarily, in pair or in small schools (adult butterfly fishes, excepting Chaetodon strigangulus and C. reticulatus after HiatT and Strasburg, 1960).

Family Acanthuridae (surgeon fishes)

Acanthurus triostegus (nom. Japan., shima-hagi) young

A. lineatus (niji-hagi) adult

A. olivaceus (montsuki-hagi) adult

A. bariene (kanran-hagi) young

A. lineolatus (naganiza) adult

A. chrysosoma (remon-hagi) young

Ctenochaetus strigosus (sazanami-hagi) adult

Prionurus microlepidotus (niza-dai) young and adult

A. lineolatus and $C$. strigosus in the waters of the Amami Islands and adult $P$. microlepidotus in Tanabe Bay occur in large schools of 50-100 individuals, though their schools are not so stable that occasionally they might break into small groups. They are not staying at any limited places but moving from deeper to shallower places with rising tide and vice versa. While, in Tanabe Bay it was observed that young fishes of $P$. microlepidotus with $5 \mathrm{~cm}$ total length occurred usually in small schools or in solitary and showed a residing tendency more strongly than in adults. But a quite different behavior is shown in a personal communication from Mr. Yoshida of the Suma Aquarium that very 
large schools of young $P$. microlepidotus are sometimes met with along the coast of Eno-shima, Kanagawa prefecture. Therefore, it is very probable that the school size may be controled by the density of young fishes in certain circumstances.

$A$. lineatus and $A$. olivaceus in the waters of the Amami Islands and $A$. bariene in Tanabe Bay, occur in small schools and hover about among the reefs. A. triostegus occurs in solitary or in small schools in Tanabe Bay, while in the waters of the Marshall Islands the species is said to live in large schools of several hundreds individuals (Hiatt and Strasburg, 1960).

On the contrary, young $A$. chrysosoma shows, in Tanabe Bay, a solitary and residing habit associated with small corals or reef rubbles.

Family Siganidae (rabbit fish)

Siganus fuscescens (nom. Japan., aigo) young and adult

Both young and adult fishes of $S$. fuscescens occur usually in schools in Tanabe Bay. According to fishermen's informations, this fish is hovering about to a great extent, although my direct observations shows that the cruising range of the young fish is not so large as in adult. Hiatr and Strasburg (1960) also observed large schools of $20-500$ individuals of $S$. rostratus on coral reefs of the Marshall Islands.

\section{Considerations on the Social Behaviors in Natural Habitats}

Hiatt and Strasburg (1960) refers to the social behaviors of 233 species of fishes inhabiting the coral reefs of the Marshall Islands in their report on the food relationships found among them. Their descriptions almost agree with my observations, but there are still a few differences between theirs and mine about some species as mentioned already.

Behavior types of some reef fishes are considered to be changeable by population density as mentioned by OKuno, NishiguchI and Kurio (1962) on the longnosed butterfly fish, Forcipiger longirostris. This fish hovers in schools under the condition of high density, while it resides in solitary under the condition of extremely low density. Young Prionurus microlepidotus is considered, as mentioned previously, to exhibit a similar behavior change in accordance with the population density. Also it is very possible that other fishes found in very unstable schools may sometimes reside in solitary under the condition of low population density and that assembling fishes may be compelled to live solitarily under the condition of low population density. Tetradrachmum tri . maculatum and $T$. reticulatum are solitary fishes in Tanabe Bay, but Dascyllus (=Tetradrachmum) aruanus is found aggregated in large number in the branching corals in the waters of the Marshall Islands.

However, the fishes such as Seriola or Caranx which form very stable schools have never been found alone or residing even under the much lowered 
density contrarily the fishes such as Pomacanthus semicirculatus and Epinephelus moara which have regular refuges have never been found aggregated even under the heightened density.

\section{Schooling Behavior in the Big Tank}

The schooling habit must be one of the most remarkable behaviors of fishes. However, it is almost impossible to make a detailed analysis of schooling behavior only by underwater observations, because there are many technical difficulties hindering exact observations and precise operations during the diving.

On the other hand, in the big tank of the Suma Aquarium shown in Fig. 4, marine fishes display the schooling behavior as well as in their natural environment. Thus, some analyses and comparisons of schooling behaviors especially in regard to the stability of the school were attempted on 15 species of fishes in this big tank.

\section{Observations on the Schooling Behavior of some Marine Fishes}

\section{(1) Material and method}

Two observations were made, the first during Nov. 19-20, 1961 and the last during Aug. 23-29, 1962*. Water temperatures during the observations are at $14.5-16.0^{\circ} \mathrm{C}$ in the former and at $26.0-27.0^{\circ} \mathrm{C}$ in the latter. Eighty five individuals belonging to 11 species were studied in the former observation and 62 individuals belonging to 10 species in the latter. All these fishes had been collected in the waters along the west coast of Kii Peninsula and in Osaka Bay during spring to summer, 1961.

Observations and recordings were made in the following way: distributions of schools or individuals of a marked species at a certain moment were projected as rapidly as possible on a printed map of the tank. This was repeated from five to twenty times a day at any available time but the hours just before, during and just after the feeding to avoid the remarkable effect of the baiting. The operation was repeated 50 times for respective species. Slight errors in recording might be inevitable on some species, as it required three to four minutes to complete a whole operation on any species holding many individuals. Neverthless I believe the whole observations were generally carried out well and successfully.

(2) Results

In most species observed individuals were generally found segregate in several small schools, but not forming any stable or compact school, except for Seriola purpurascens.

\footnotetext{
* Besides, a supplemental observation on Trachurus japonicus was made on June 16, 1963.
} 
In order to compare the schooling tendencies of observed fishes one another, the frequency of occurrence of respcective school sizes and total number of individuals appeared in respective school sizes were calculated on respective species (Tables 5 and 6).

Thirteen individuals of $S$. purpurascens were found generally in the most stable school but only two of 50 examination when they were separated into two schools (Table 5). On the other hand, 17 individuals of Prionurus microlepidotus in the first observation were never found in a single school but generally segregated in several schools, solitary individuals being met with frequently (Table 5).

To learn the specific characteristics of schooling behavior, two indices, "solitary rate" and "schooling rate", are proposed and calculated for each species. Solitary rate: This is the rate, the number of solitary individuals to the number of total individuals of respective species and it is high in the species forming unstable schools, as many individuals are always apt to stray out from the school in such species. There are two types of solitary individuals. One is the hovering solitary and the other is the residing solitary type. In the former individuals swimming around solitarily may return to the school whenever they meet it. This type was observed in Parapristipoma trilineatum, Chrysophrys major, Lutjanus rivulatus, L. russelli and Kyphosus lembus. While, in the latter type, solitary individuals are usually residing under the ledges or in the caves of rock and sometimes they even try to defend their own residing places against the schooling individuals of the same species. Such a behavior was observed most evidently in Prionurus microlepidotus and occasionally in Siganus fuscescens, Chaetodon collaris, Microcanthus strigatus, Girella punctata and G. melanichthys.

Schooling rate: The rate is represented by the percentage of averge number of component individuals of schools $(A)$ to the number of specimens of respective species observed $(\mathrm{B})$ as $\mathrm{A} / \mathrm{B} \times 100$.

When all the specimens of a certain species are always gathered into a single school, this index is 100 , while if all of them are solitary, the index will be 0 . There is evidently the possibility that the index might be much larger than the real value in the cases where only small numbers of specimens are treated with. This index is, therefore, applicable only to the cases in which at least more than five specimens are included.

On the data shown in Tables 5 and 6 , the following four groups may be distinguished one another concerning the stability of the school:

1) Seriola purpurascens forms the most perfect and stable schools as compared with other species. Solitary and schooling rates of this fish were respectively 0 and 96 in the first observation (Table 5) and the same trend was assumed in the second observation, too (Table 6). 
Table 5. Stability of school observed on 11 species in the big tank. Results of the first observation.

\begin{tabular}{|c|c|c|c|c|c|c|c|c|c|c|c|c|c|c|c|c|c|c|c|c|}
\hline & $\begin{array}{c}\text { Number } \\
\text { of } \\
\text { specimen }\end{array}$ & $\begin{array}{l}\text { Total } \\
\text { length } \\
\text { in } \mathrm{cm}\end{array}$ & \multicolumn{13}{|c|}{ Number of component individuals of respective school } & Total & $\begin{array}{l}\text { Solitary } \\
\text { rate }\end{array}$ & $\begin{array}{l}\text { Average } \\
\text { number of } \\
\text { fishes per } \\
\text { school } \\
\text { (A) }\end{array}$ & $\begin{array}{c}\text { Average } \\
\text { number of } \\
\text { observed } \\
\text { fishes } \\
\text { (B) }\end{array}$ & $\begin{array}{l}\text { Schooling } \\
\text { rate } \\
\mathbf{A} / \mathbf{B} \times 100\end{array}$ \\
\hline Seriola purpurascens & 13 & 30 & $\begin{array}{l}0 \\
0\end{array}$ & $\begin{array}{l}0 \\
0\end{array}$ & $\begin{array}{l}0 \\
0\end{array}$ & $\begin{array}{l}1 \\
4\end{array}$ & $\begin{array}{l}1 \\
5\end{array}$ & $\begin{array}{l}0 \\
0\end{array}$ & $\begin{array}{l}0 \\
0\end{array}$ & $\begin{array}{l}1 \\
8\end{array}$ & $\begin{array}{l}1 \\
9\end{array}$ & $\begin{array}{l}0 \\
0\end{array}$ & $\begin{array}{l}0 \\
0\end{array}$ & $\begin{array}{l}0 \\
0\end{array}$ & $\begin{array}{r}48 \\
624\end{array}$ & $\begin{array}{r}52 \\
650\end{array}$ & 0 & 12.5 & 13 & 96 \\
\hline Parapristipoma trilineatum & 6 & 30 & $\begin{array}{l}7 \\
7\end{array}$ & $\begin{array}{r}6 \\
12\end{array}$ & $\begin{array}{l}13 \\
39\end{array}$ & $\begin{array}{r}5 \\
20\end{array}$ & $\begin{array}{r}6 \\
30\end{array}$ & $\begin{array}{r}32 \\
192\end{array}$ & * & * & * & $\begin{array}{l}* \\
*\end{array}$ & $\begin{array}{l}* \\
*\end{array}$ & * & $\begin{array}{l}* \\
*\end{array}$ & $\begin{array}{r}69 \\
300\end{array}$ & 2.3 & 4.7 & 6 & 79 \\
\hline Lutjanus rivulatus & 5 & $20-30$ & $\begin{array}{l}27 \\
27\end{array}$ & $\begin{array}{l}10 \\
20\end{array}$ & $\begin{array}{l}14 \\
42\end{array}$ & $\begin{array}{l}14 \\
56\end{array}$ & $\begin{array}{r}21 \\
105\end{array}$ & $\begin{array}{l}* \\
*\end{array}$ & $\begin{array}{l}* \\
*\end{array}$ & $\begin{array}{l}* \\
*\end{array}$ & * & $\begin{array}{l}* \\
*\end{array}$ & $\begin{array}{l}* \\
*\end{array}$ & $\begin{array}{l}* \\
*\end{array}$ & $\begin{array}{l}* \\
*\end{array}$ & $\begin{array}{r}87 \\
250\end{array}$ & 10.8 & 3.7 & 5 & 74 \\
\hline Siganus fuscescens & 13 & $\begin{array}{l}25 \times 2 \\
30 \times 11\end{array}$ & $\begin{array}{l}34 \\
34\end{array}$ & $\begin{array}{l}15 \\
30\end{array}$ & $\begin{array}{l}13 \\
39\end{array}$ & $\begin{array}{l}1 \\
4\end{array}$ & $\begin{array}{r}6 \\
30\end{array}$ & $\begin{array}{r}8 \\
48\end{array}$ & $\begin{array}{r}9 \\
63\end{array}$ & $\begin{array}{r}7 \\
56\end{array}$ & $\begin{array}{r}3 \\
27\end{array}$ & $\begin{array}{r}7 \\
70\end{array}$ & $\begin{array}{r}8 \\
88\end{array}$ & $\begin{array}{r}6 \\
72\end{array}$ & $\begin{array}{r}6 \\
78\end{array}$ & $\begin{array}{l}123 \\
639\end{array}$ & 5.3 & 6.8 & 12.8 & 53 \\
\hline Chrysophrys major & 9 & 15 & $\begin{array}{l}39 \\
39\end{array}$ & $\begin{array}{l}27 \\
54\end{array}$ & $\begin{array}{l}10 \\
30\end{array}$ & $\begin{array}{l}12 \\
48\end{array}$ & $\begin{array}{r}9 \\
45\end{array}$ & $\begin{array}{r}8 \\
48\end{array}$ & $\begin{array}{r}7 \\
49\end{array}$ & $\begin{array}{r}7 \\
56\end{array}$ & $\begin{array}{r}9 \\
81\end{array}$ & * & $\begin{array}{l}* \\
*\end{array}$ & $\begin{array}{l}* \\
*\end{array}$ & $\begin{array}{l}* \\
*\end{array}$ & $\begin{array}{l}128 \\
450\end{array}$ & 8.7 & 4.6 & 9 & 51 \\
\hline Prionurus microlepidotus & 17 & $15-25$ & $\begin{array}{l}232 \\
232\end{array}$ & $\begin{array}{r}61 \\
122\end{array}$ & $\begin{array}{l}17 \\
51\end{array}$ & $\begin{array}{l}21 \\
84\end{array}$ & $\begin{array}{l}18 \\
90\end{array}$ & $\begin{array}{r}3 \\
18\end{array}$ & $\begin{array}{r}8 \\
56\end{array}$ & $\begin{array}{r}5 \\
40\end{array}$ & $\begin{array}{r}3 \\
27\end{array}$ & $\begin{array}{l}0 \\
0\end{array}$ & $\begin{array}{r}1 \\
11\end{array}$ & $\begin{array}{r}2 \\
24\end{array}$ & $\begin{array}{l}0 \\
0\end{array}$ & $\begin{array}{l}371 \\
760\end{array}$ & 30.5 & 3.8 & 15.2 & 25 \\
\hline Kyphosus lembus & 4 & 25 & $\begin{array}{l}52 \\
52\end{array}$ & $\begin{array}{l}12 \\
24\end{array}$ & $\begin{array}{l}32 \\
96\end{array}$ & $\begin{array}{r}7 \\
28\end{array}$ & $\begin{array}{l}* \\
*\end{array}$ & $\begin{array}{l}* \\
*\end{array}$ & * & $\begin{array}{l}* \\
*\end{array}$ & $\begin{array}{l}* \\
*\end{array}$ & * & $\begin{array}{l}* \\
*\end{array}$ & $\begin{array}{l}* \\
*\end{array}$ & * & $\begin{array}{l}1.03 \\
200\end{array}$ & 26.0 & 2.9 & 4 & 73 \\
\hline Chaetodon collaris & 6 & 13 & $\begin{array}{l}226 \\
226\end{array}$ & $\begin{array}{l}17 \\
34\end{array}$ & $\begin{array}{r}7 \\
21\end{array}$ & $\begin{array}{l}2 \\
8\end{array}$ & $\begin{array}{l}1 \\
5\end{array}$ & $\begin{array}{l}1 \\
6\end{array}$ & * & * & $*$ & * & $*$ & * & * & $\begin{array}{l}254 \\
300\end{array}$ & 75.3 & 1.2 & 6 & 44 \\
\hline Epinephelus moara & 4 & $\begin{array}{l}40 \times 2 \\
80 \times 2\end{array}$ & $\begin{array}{l}200 \\
200\end{array}$ & $\begin{array}{l}0 \\
0\end{array}$ & $\begin{array}{l}0 \\
0\end{array}$ & $\begin{array}{l}0 \\
0\end{array}$ & * & * & * & $\begin{array}{l}* \\
*\end{array}$ & * & * & * & $\begin{array}{l}* \\
*\end{array}$ & * & $\begin{array}{l}200 \\
200\end{array}$ & 100 & - & - & - \\
\hline Semicossyphus reticulatus & 2 & 50,60 & $\begin{array}{l}100 \\
100\end{array}$ & $\begin{array}{l}0 \\
0\end{array}$ & * & * & $*$ & * & * & $*$ & $\begin{array}{l}* \\
*\end{array}$ & * & $*$ & * & $*$ & $\begin{array}{l}100 \\
100\end{array}$ & 100 & - & - & - \\
\hline Bodianus perditio & 5 & 35 & $\begin{array}{l}250 \\
250\end{array}$ & $\begin{array}{l}0 \\
0\end{array}$ & $\begin{array}{l}0 \\
0\end{array}$ & $\begin{array}{l}0 \\
0\end{array}$ & $\begin{array}{l}0 \\
0\end{array}$ & $\begin{array}{l}* \\
*\end{array}$ & $\begin{array}{l}* \\
*\end{array}$ & * & * & $\begin{array}{l}* \\
*\end{array}$ & * & $\begin{array}{l}* \\
*\end{array}$ & * & $\begin{array}{l}250 \\
250\end{array}$ & 100 & - & - & - \\
\hline \multicolumn{21}{|c|}{ Total 11 species 85 specimens } \\
\hline
\end{tabular}


Table 6. Stability of school observed on 11 species in the big tank

Results of the second and supplemental observations.

\begin{tabular}{|c|c|c|c|c|c|c|c|c|c|c|c|c|c|c|c|c|c|c|c|c|c|}
\hline & $\begin{array}{c}\text { Number } \\
\text { of } \\
\text { specimen }\end{array}$ & \multirow{2}{*}{$\begin{array}{l}\begin{array}{c}\text { Total } \\
\text { length } \\
\text { in } \mathrm{cm}\end{array} \\
20-30\end{array}$} & 1 & \multicolumn{11}{|c|}{ Number of component individuals of respective school } & 13 & Total & $\begin{array}{l}\text { Solitary } \\
\text { rate }\end{array}$ & $\begin{array}{l}\text { Average } \\
\text { number of } \\
\text { fishes per } \\
\text { school } \\
\text { (A) }\end{array}$ & $\begin{array}{l}\text { Average } \\
\text { number of } \\
\text { observed } \\
\text { fishes } \\
\text { (B) }\end{array}$ & \multicolumn{2}{|c|}{$\begin{array}{l}\text { Schooling } \\
\text { rate } \\
\mathrm{A} / \mathrm{B} \times 100\end{array}$} \\
\hline Prionurus microlepidotus & 15 & & $\begin{array}{l}263 \\
263\end{array}$ & $\begin{array}{r}80 \\
160\end{array}$ & $\begin{array}{l}33 \\
99\end{array}$ & $\begin{array}{r}9 \\
36\end{array}$ & $\begin{array}{l}11 \\
55\end{array}$ & $\begin{array}{r}6 \\
36\end{array}$ & $\begin{array}{r}2 \\
16\end{array}$ & $\begin{array}{r}4 \\
32\end{array}$ & $\begin{array}{l}1 \\
9\end{array}$ & $\begin{array}{l}0 \\
0\end{array}$ & 11 & $\begin{array}{r}1 \\
12\end{array}$ & $\begin{array}{r}1 \\
13\end{array}$ & $\begin{array}{l}412 \\
738\end{array}$ & 35.7 & 2.9 & 14.8 & 20 & \\
\hline Microcanthus strigatus & 10 & $10-13$ & $\begin{array}{l}94 \\
94\end{array}$ & $\begin{array}{l}25 \\
50\end{array}$ & $\begin{array}{r}9 \\
27\end{array}$ & $\begin{array}{l}18 \\
72\end{array}$ & $\begin{array}{r}5 \\
25\end{array}$ & $\begin{array}{r}8 \\
48\end{array}$ & $\begin{array}{r}9 \\
63\end{array}$ & $\begin{array}{r}7 \\
56\end{array}$ & $\begin{array}{r}5 \\
45\end{array}$ & $\begin{array}{r}2 \\
20\end{array}$ & $\begin{array}{l}* \\
*\end{array}$ & $\begin{array}{l}* \\
*\end{array}$ & $\begin{array}{l}* \\
*\end{array}$ & $\begin{array}{l}182 \\
500\end{array}$ & 18.8 & 4.6 & 10 & 46 & \\
\hline Girella punctata (adult) & 3 & $30-35$ & $\begin{array}{l}76 \\
76\end{array}$ & $\begin{array}{l}16 \\
32\end{array}$ & $\begin{array}{l}14 \\
42\end{array}$ & * & $\begin{array}{l}* \\
*\end{array}$ & * & $\begin{array}{l}* \\
*\end{array}$ & * & $\begin{array}{l}* \\
*\end{array}$ & * & * & $*$ & * & $\begin{array}{l}106 \\
150\end{array}$ & 49.4 & 2.5 & 3 & 83 & Numbers of \\
\hline Girella melanichthys (adult) & 3 & $25-30$ & $\begin{array}{l}59 \\
59\end{array}$ & $\begin{array}{l}14 \\
28\end{array}$ & $\begin{array}{l}1 \\
3\end{array}$ & $\begin{array}{l}* \\
*\end{array}$ & $\begin{array}{l}* \\
*\end{array}$ & $\begin{array}{l}* \\
*\end{array}$ & $\begin{array}{l}* \\
*\end{array}$ & $\begin{array}{l}* \\
*\end{array}$ & $\begin{array}{l}* \\
*\end{array}$ & $\begin{array}{l}* \\
*\end{array}$ & $\begin{array}{l}* \\
*\end{array}$ & $\begin{array}{l}* \\
*\end{array}$ & $\begin{array}{l}* \\
*\end{array}$ & $\begin{array}{l}74 \\
90\end{array}$ & 65.6 & 2.1 & 3 & 70 & $\begin{array}{l}\text { observation } \\
\text { are } 30 \text { times. }\end{array}$ \\
\hline $\begin{array}{l}\text { G. punctata and } \\
\text { G. melanichthys (young)* }\end{array}$ & 12 & $\begin{array}{l}12 \times 10 \\
20,22\end{array}$ & $\begin{array}{l}70 \\
70\end{array}$ & $\begin{array}{l}24 \\
48\end{array}$ & $\begin{array}{r}8 \\
24\end{array}$ & $\begin{array}{l}10 \\
40\end{array}$ & $\begin{array}{r}8 \\
40\end{array}$ & $\begin{array}{r}6 \\
36\end{array}$ & $\begin{array}{r}6 \\
42\end{array}$ & $\begin{array}{r}4 \\
32\end{array}$ & $\begin{array}{r}6 \\
54\end{array}$ & $\begin{array}{r}8 \\
80\end{array}$ & $\begin{array}{r}10 \\
110\end{array}$ & $\begin{array}{r}2 \\
24\end{array}$ & $\begin{array}{l}* \\
*\end{array}$ & $\begin{array}{l}162 \\
600\end{array}$ & 12.7 & 5.8 & 12 & 48 & \\
\hline Chaetodon collaris & 3 & $12-18$ & $\begin{array}{l}114 \\
114\end{array}$ & $\begin{array}{l}15 \\
30\end{array}$ & $\begin{array}{l}0 \\
0\end{array}$ & $\begin{array}{l}* \\
*\end{array}$ & * & $\begin{array}{l}* \\
*\end{array}$ & $\begin{array}{l}* \\
*\end{array}$ & $\begin{array}{l}* \\
*\end{array}$ & $\begin{array}{l}* \\
*\end{array}$ & $\begin{array}{l}* \\
*\end{array}$ & $\begin{array}{l}* \\
*\end{array}$ & $\begin{array}{l}* \\
*\end{array}$ & * & $\begin{array}{l}129 \\
144\end{array}$ & 71.1 & 2 & 3 & 67 & $\begin{array}{l}\text { observation } \\
\text { are } 48 \text { times. }\end{array}$ \\
\hline Lutjanus russelli & 2 & 30 & $\begin{array}{l}32 \\
32\end{array}$ & $\begin{array}{l}34 \\
68\end{array}$ & $\begin{array}{l}* \\
*\end{array}$ & * & $\begin{array}{l}* \\
*\end{array}$ & $\begin{array}{l}* \\
*\end{array}$ & * & $\begin{array}{l}* \\
*\end{array}$ & * & $\begin{array}{l}* \\
*\end{array}$ & $\begin{array}{l}* \\
*\end{array}$ & * & $\begin{array}{l}* \\
*\end{array}$ & $\begin{array}{r}66 \\
100\end{array}$ & 32.0 & 2 & 2 & 100 & Numbers of \\
\hline Seriola purpurascens & 2 & 40 & $\begin{array}{l}6 \\
6\end{array}$ & $\begin{array}{l}37 \\
74\end{array}$ & * & * & * & * & * & $\begin{array}{l}* \\
*\end{array}$ & * & * & * & $\begin{array}{l}* \\
*\end{array}$ & $*$ & $\begin{array}{l}43 \\
80\end{array}$ & 7.5 & 2 & 2 & 100 & $\begin{array}{l}\text { observation } \\
\text { are } 40 \text { times. }\end{array}$ \\
\hline Siganus fuscescens & 2 & 30 & $\begin{array}{l}28 \\
28\end{array}$ & $\begin{array}{l}36 \\
72\end{array}$ & * & * & * & * & * & * & * & $*$ & $*$ & $*$ & $*$ & $\begin{array}{r}64 \\
100\end{array}$ & 28.0 & 2 & 2 & 100 & \\
\hline Epinephelus moara & 5 & $30-50$ & $\begin{array}{l}250 \\
250\end{array}$ & $\begin{array}{l}0 \\
0\end{array}$ & $\begin{array}{l}0 \\
0\end{array}$ & $\begin{array}{l}0 \\
0\end{array}$ & $\begin{array}{l}0 \\
0\end{array}$ & * & * & $*$ & $*$ & $*$ & * & $*$ & * & $\begin{array}{l}250 \\
250\end{array}$ & 100 & - & - & - & \\
\hline Semicossyphus reticulatus & 5 & $45-60$ & $\begin{array}{l}250 \\
250\end{array}$ & $\begin{array}{l}0 \\
0\end{array}$ & $\begin{array}{l}0 \\
0\end{array}$ & $\begin{array}{l}0 \\
0\end{array}$ & $\begin{array}{l}0 \\
0\end{array}$ & * & * & * & * & * & * & $\begin{array}{l}* \\
*\end{array}$ & $\begin{array}{l}* \\
*\end{array}$ & $\begin{array}{l}250 \\
250\end{array}$ & 100 & - & - & - & Supplemental \\
\hline Trachurus japonicus & 6 & 15 & $\begin{array}{l}9 \\
9\end{array}$ & $\begin{array}{r}8 \\
16\end{array}$ & $\begin{array}{r}6 \\
18\end{array}$ & $\begin{array}{r}7 \\
28\end{array}$ & $\begin{array}{r}5 \\
25\end{array}$ & $\begin{array}{r}34 \\
204\end{array}$ & $\begin{array}{l}* \\
*\end{array}$ & $\begin{array}{l}* \\
*\end{array}$ & $\begin{array}{l}* \\
*\end{array}$ & $\begin{array}{l}* \\
*\end{array}$ & * & $\begin{array}{l}* \\
*\end{array}$ & * & $\begin{array}{r}69 \\
300\end{array}$ & 3.0 & 4.9 & 6 & 82 & $\begin{array}{l}\text { observation on } \\
\text { June } 16,1963 .\end{array}$ \\
\hline \multicolumn{22}{|c|}{ Total 11 species 68 specimens } \\
\hline
\end{tabular}

* In this case, result is of the compound population of two species of Girella, since they form together perfectly mixed schools in the tank as in the sea (Okuno, 1962). 
2) The next grade of stable schooling is represented by Parapristipoma trilineatum and Trachurus japonicus. Solitary and schooling rates of these fishes were respectively 2.3 and 79 in the former and 3.0 and 82 in the latter.

3) Siganus fuscescens, Chrysophrys major, Lutjanus rivulatus, Microcanthus strigatus and Kyphosus lembus show an intermediate state of stable schooling. The solitary rates were respectively $5.3,8.7,10.8,18.8$ and 26.0 , while the schooling rate were respectively 53,51,74, 46 and 73 . Relatively larger schooling rates of $L$. rivulatus and $K$. lembus may be attributable to the fewness of the specimens dealt with, since their solitary rates are larger than those of S. fuscescens and C. major. Young fishes of Girella punctata and G. melanichthys formed together perfectly mixed schools in the tank as in the sea and thus solitary and schooling rates were calculated on such mixed schools as respectively 12.7 and 48 .

4) The most unstable state of schooling was seen in Prionurus microlepidotus and Chaetodon collaris. The solitary and schooling rates were respectively 30.5 and 25 in the first observation and 35.7 and 20 in the second for the former and 75.3 and 44 in the first observation for the latter. A similar state of schooling was recognized on $C$. collaris in the second observation.

Epinephelus moara and Semicossyphus reticulatus in the first and second observations and Bodianus perditio in the first observation showed a perfectly solitary behavior.

The data about Girella punctata (adult), G. melanichthys (adult) and L. russelli are not available as the treated specimens were too scarce. However, the solitary and schooling rates and the behaviors of solitary individuals seem to allude that G. punctata and G. melanichthys belong to the 4th type, while L. russelli to the 3rd.

Total number of individuals appeared in respective sizes of schools or groups is shown in histograms in Fig. $6 \mathrm{a}-\mathrm{k}$ on the data of Tables 5 and 6.

Four types of schooling behavior above mentioned are also distinguishable in the histograms of Fig. 6. The histogram for $S$. purpurascens indicate that nearly all individuals of this species belong to the largest school (Type 1). The histograms for $T$. trilineatum, L. rivulatus and Trachurus japonicus show that individual number increase from left to right (type 2). The histograms for $S$. fuscescens, C. major, $M$. strigatus and young fishes of two Girella exhibit that individual numbers do not change remarkably form left to right, i.e., they form schools of various sizes evenly (Type 3). The histograms for P. microlepidotus and $C$. collaris indicate that individual numbers decrease from left to right, namely these species have a dispersing tendency (type 4). The tendencies read on these histograms coincide almost with those obtained from the schooling and solitary rates, except for $L$. rivulatus.

Fishes of types 1),2) and L. rivulatus, $K$, lembus and L. russelli of type 3) never show the residing behavior, even when individuals are straying out from the school. On the other hand, solitary individuals of other fishes of type 3) 

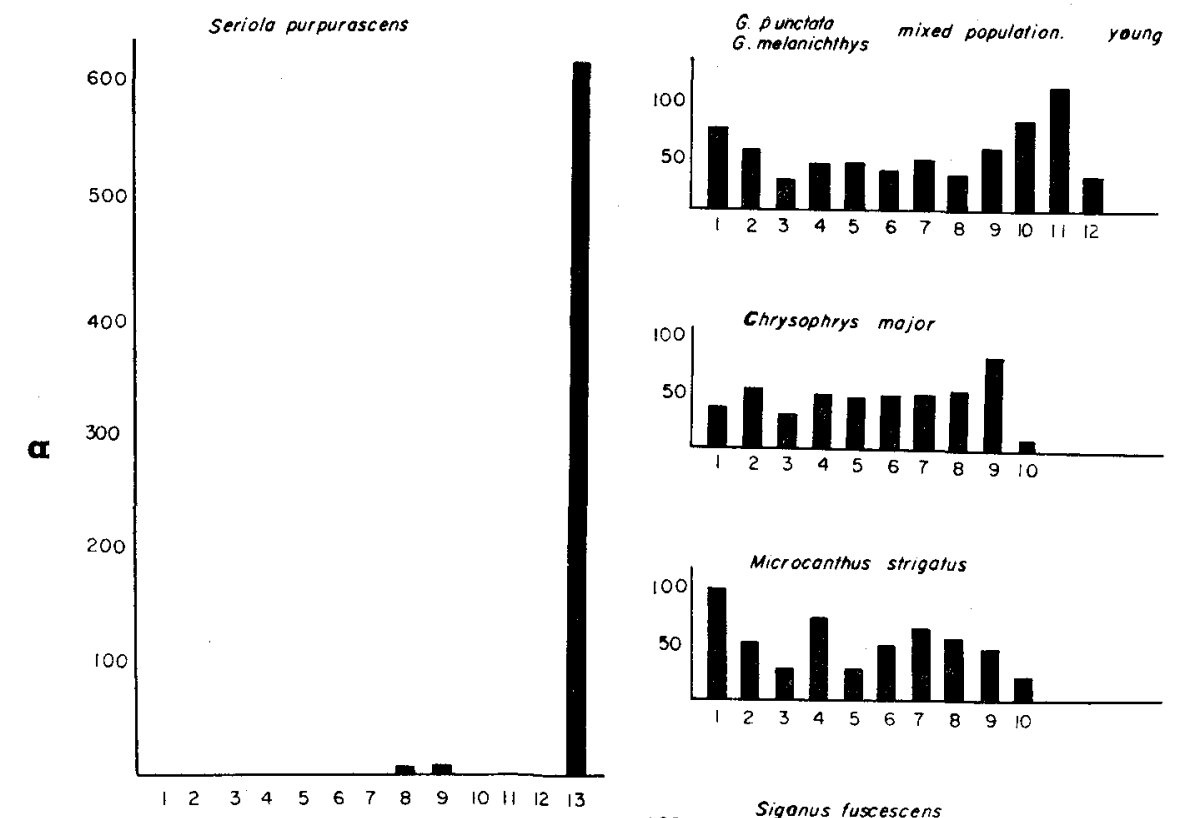

e
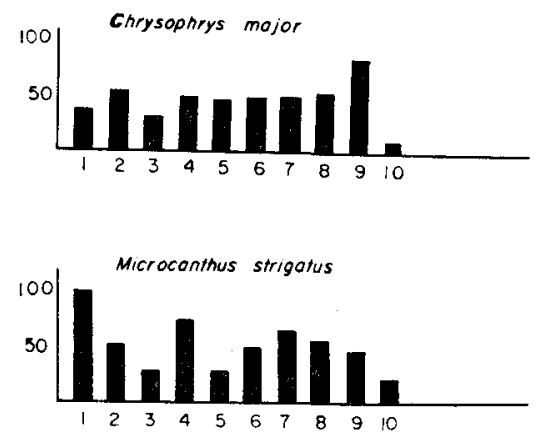

f

g
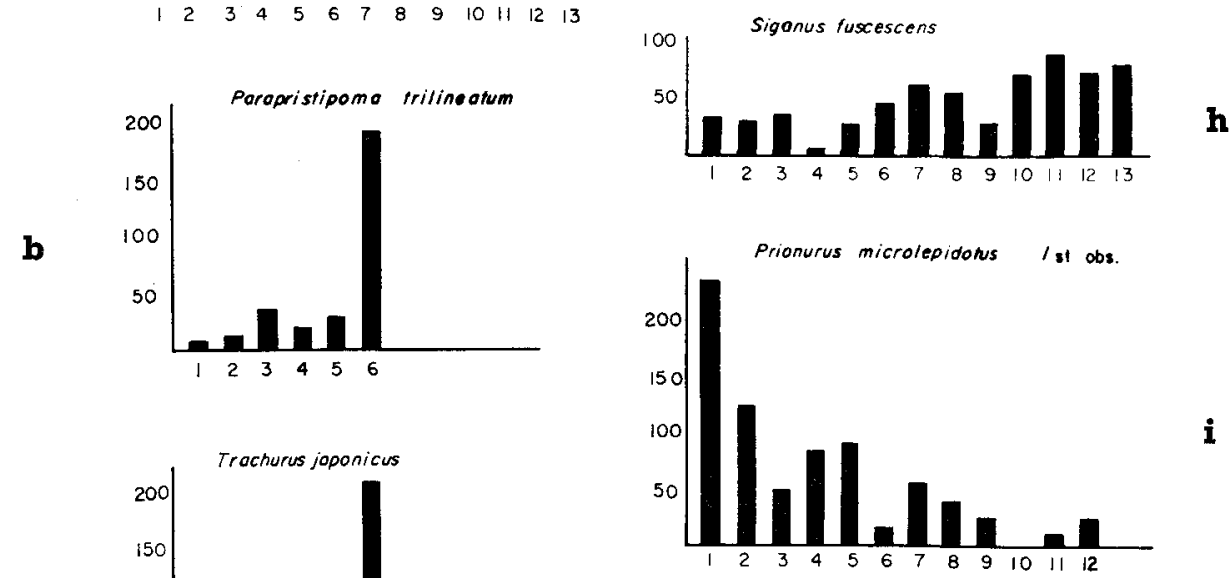

c

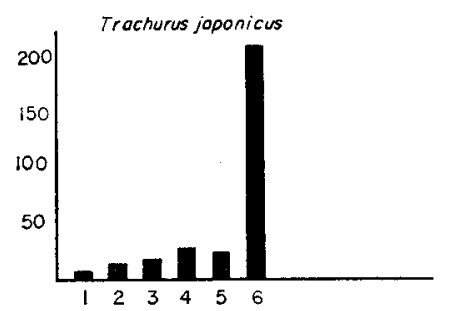

d
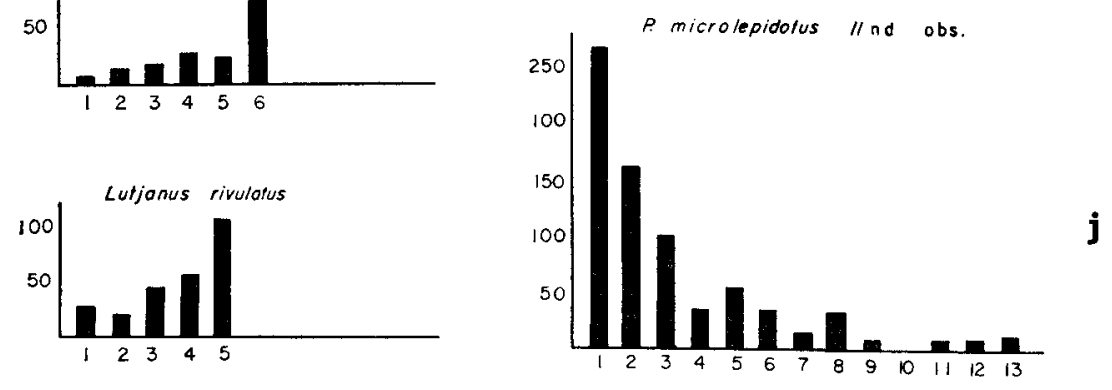


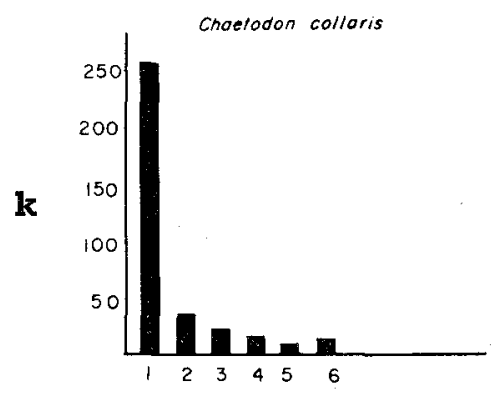

Text-fig. 6 a-k. Stability of schooling behavior in the big tank, given in histograms showing the number of total individuals appeared in respective sizes of schools.

such as S. fuscescens, C. major, M. strigatus and young Girella are sometimes staying at certain places among rocks. Residing and territorial behaviors are commonly seen in solitary individuals of type 4), especially of P. microlepidotus. During another observation in this tank made for other purposes, a individual of this species was found residing at a certain place and defending it against other individuals for more than one month.

Schooling behaviors of S. purpurascens, P. trilineatum, S. fuscescens, L. russelli, M. strigatus, K. lembus, adult and young Girella, P. microlepidotus and C. collaris have been actually observed in their natural environments. And it may be concluded that most fishes exhibit in such big tank, social behaviors similar to those in their natural habitats.

\section{Relationships between Girella punctata and G. melanichthys in regard to Their Schooling Habits}

It is already reported in my previous paper (OKuno, $1962 \mathrm{~b}$ ) that young $G$. punctata and $G$. melanichthys form the common school perfectly mixed in the sea, while adults of these fishes form their own schools distinctly separated from each other. The same tendency was observed in the big tank as mentioned above.

(1) Material and method

Young individuals of these two fishes for the observations were collected in Tanabe Bay in Sept. 1961, and reared in a small tank at the Suma Aquarium. Adults of these fishes were obtained in the waters along the west coast of Kii Peninsula in the years 1960-1961 and were reared in small tanks or in the big tank.

Observations were made twice, the dates and the total length of indivuduals observed are shown in Tables 7 and 8 . Individual discrimination was made only on adult fishes. Individual $C$ of adult $G$. melanichthys died during the first observation: thus the number of individuals of G. melanichthys was three in the 
Table 7. Dates of observations made on the compound school of Girella spp. in the big tank.

\begin{tabular}{c|c|c|c|c}
\hline \hline Aug. 1962 & 22 & 23 & $24-29$ & 30 \\
\hline Operation & Marking & Stocked & Ist Observation & IInd observation \\
\hline
\end{tabular}

Table 8. Total length of specimens observed (in $\mathrm{cm}$ ).

\begin{tabular}{|c|c|c|c|c|c|c|c|}
\hline & \multicolumn{6}{|c|}{ Total length in $\mathrm{cm}$. } & \multirow{2}{*}{ Mean } \\
\hline & $\mathrm{A}$ & $\mathrm{B}$ & $\mathrm{C}$ & $\mathrm{D}$ & $\mathrm{E}$ & $\mathbf{F}$ & \\
\hline G. punctata (adult) & about 35 & about 33 & about 30 & 29.0 & 27.5 & - & 31 \\
\hline G. melanichthys (adult) & about 30 & about 32 & 29.5 & 29.5 & 27.5 & - & 30 \\
\hline G. punctata (young) & 19.8 & 12.5 & 13.4 & 13.1 & 13.2 & 13.0 & 13.0 \\
\hline G. melanichthys (young) & 22.0 & 11.6 & 13.2 & 13.0 & 14.2 & 12.5 & 12.9 \\
\hline
\end{tabular}

Table 9. Interrelations between the schooling behaviors of adult and young G. punctata and G. melanichthys.

\begin{tabular}{|c|c|c|c|c|}
\hline & \multicolumn{2}{|c|}{ Adult } & \multicolumn{2}{|c|}{ Young } \\
\hline & $\begin{array}{l}\text { First } \\
\text { observ. }\end{array}$ & $\begin{array}{l}\text { Second } \\
\text { observ. }\end{array}$ & $\begin{array}{l}\text { First } \\
\text { observ. }\end{array}$ & $\begin{array}{l}\text { Second } \\
\text { observ. }\end{array}$ \\
\hline \multicolumn{5}{|l|}{ Number of soritaly } \\
\hline punctata & 79 & 169 & 32 & 60 \\
\hline melanichthys & 81 & 110 & 8 & 25 \\
\hline total & 160 & 279 & 40 & 85 \\
\hline \multicolumn{5}{|l|}{ Number of simple school } \\
\hline punctata & 22 & 28 & 1 & 9 \\
\hline melanichthys & 19 & 47 & 3 & 5 \\
\hline total $(\mathrm{A})$ & 41 & 76 & 4 & 13 \\
\hline $\begin{array}{l}\text { Number of compound school } \\
\text { punstata-melanichthys (B) }\end{array}$ & 8 & 14 & 73 & 58 \\
\hline Total number of school (A) $+(\mathrm{B})$ & 49 & 90 & 77 & 62 \\
\hline $\begin{array}{l}\text { Number of individuals appeared in simple } \\
\text { school (C) }\end{array}$ & 93 & 162 & 9 & 34 \\
\hline $\begin{array}{l}\text { Number of individuals appeared in compound } \\
\text { school (D) }\end{array}$ & 27 & 59 & 551 & 481 \\
\hline $\begin{array}{l}\text { Total number of individuals appeared in both } \\
\text { schools (C) }+ \text { (D) }\end{array}$ & 120 & 221 & 560 & 515 \\
\hline $\begin{array}{l}\text { Percentage of simple schools to total school } \\
\mathrm{A} /(\mathrm{A}+\mathrm{B}) \times 100\end{array}$ & 83.7 & 84.4 & 5.2 & 18.0 \\
\hline $\begin{array}{l}\text { Percentage of individuals appeared in simple } \\
\text { school to total individuals } \mathrm{C} /(\mathrm{C}+\mathrm{D}) \times 100\end{array}$ & 77.5 & 73.3 & 1.5 & 5.7 \\
\hline
\end{tabular}


first 30 operations but two in the last 20 . General method of observation is the same as that mentioned in the beginning part of this chapter.

(2) Results

As shown in Table 9, it is evident that young fishes of the two species of Girella form perfect compound schools in the big tank, too, while adults never do so. Rate of simple school formation was $83.7 \%$ and $84.4 \%$ in adults, but only $5.2 \%$ and $18.0 \%$ in youngers. The similar trend is shown also by the rate of the number of individuals forming simple schools. The rate was $77.5 \%$ and $73.3 \%$ in adults, while $1.5 \%$ and $5.7 \%$ in youngers.

The tendencies concerning young fishes, coincide perfectly with those observed in the sea (Окuno, $1962 \mathrm{~b}$ ). And as to the adult fishes, the results of the present experimental observations seem to reinforce the assumption presented in my provious paper.

\section{Chasing Behavior in the Small Tank}

\section{Changes of Fish Behavior in Captivity}

The data presented in Table 10 indicate the distribution of the chasing behavior among 216 species of fishes in small tanks. These data were obtained by observations made on fishes kept in show tanks at the Suma Aquarium in the years $1957-1962$.

This table seems to indicate that the distribution is related closely with the systematic situations of fishes.

1) No chasing behavior has ever been observed in fishes of the class Chondrichthyes* (16 species of sharks and rays observed) and those of the order Anguillida (11 species of eels and moray eels observed**).

2) Most species of the order Percida show the chasing behavior (111 of 125 species observed), although the fishes of the suborders Scombrina and Carangina of the same order never show the chasing habit (all of the five species observed).

3) All of the observed species of the suborder Pomacentrina, Labrina and Chaetodontina show the chasing habit.

It appears that the intrinsically intense and stable schooling habit prevents the fishes of the suborders Scombrina and Carangina to chase one another even in the small tank, as some species having the relatively stable schooling habit such as Parapristipoma trilineatum of the suborder Percina did not show any

*. It is sured by AlLEE and DICkINson (1954) that the smooth dogfish, Mustelus canis (Mitchill) does not chase one another in tanks.

** Moray eels sometimes threated companions by opening widely their mouths, although chasing behavior is never observed. 
Table 10. The distribution of chasing behavior in 216 species of fishes. Numerals indicate the number of species.

\begin{tabular}{|c|c|c|c|}
\hline & $\begin{array}{c}\text { Number of } \\
\text { observed } \\
\text { species }\end{array}$ & Fighting & No fighting \\
\hline \multicolumn{4}{|l|}{ Class Chondrichthyes } \\
\hline Order Lamnida & 8 & 0 & 8 \\
\hline Order Rajida & 8 & 0 & 8 \\
\hline \multicolumn{4}{|l|}{ Class Teleostomi } \\
\hline \multicolumn{4}{|l|}{ Order Clupeida } \\
\hline Suborder Clupeina & 1 & 0 & 1 \\
\hline Suborder Salmonina & 4 & 4 & 0 \\
\hline \multicolumn{4}{|l|}{ Order Cyprinida } \\
\hline Suborder Cyprinina & 17 & 8 & 9 \\
\hline Suborder Silurina & 4 & 1 & 3 \\
\hline Order Anguillida & 11 & 0 & 11 \\
\hline Order Cyprinodontida & 1 & 1 & 0 \\
\hline Order Gasterosteida & 2 & 2 & 0 \\
\hline Order Syngnathida & 6 & 1 & 5 \\
\hline \multicolumn{4}{|l|}{ Order Percida } \\
\hline Suborder Mugilina & 1 & 0 & $\mathbf{1}$ \\
\hline Suborder Scombrina & 1 & 0 & 1 \\
\hline Suborder Carangina & 4 & 0 & 4 \\
\hline Suborder Percina & 54 & 47 & 7 \\
\hline Suborder Ammodytina & 1 & 0 & 1 \\
\hline Suborder Blenniina & 4 & 4 & 0 \\
\hline Suborder Gobiina & 4 & 4 & 0 \\
\hline Suborder Pomacentrina & 20 & 20 & 0 \\
\hline Suborder Labrina & 12 & 12 & 0 \\
\hline Soborder Chaetodontina & 23 & 23 & 0 \\
\hline Suborder Siganina & 1 & 1 & 0 \\
\hline \multicolumn{4}{|l|}{ Order Tetraodontida } \\
\hline Suborder Balistina & 8 & 7 & 1 \\
\hline Suborder Ostraciontina & 1 & 0 & 1 \\
\hline Suborder Tetraodontina & 5 & 5 & 0 \\
\hline \multicolumn{4}{|l|}{ Order Cottida } \\
\hline Suborder Cottina & 10 & 5 & 5 \\
\hline Suborder Dactylopterina & 1 & 0 & 1 \\
\hline Order Echeneida & 1 & 1 & 0 \\
\hline Order Symbranchida & 1 & 0 & 1 \\
\hline Order Lophiida & 2 & 0 & 2 \\
\hline Total & 216 & $146(68 \%)$ & $70(32 \%)$ \\
\hline Saltwater fishes & 186 & $129(69 \%)$ & $57(31 \%)$ \\
\hline Freshwater fishes & 30 & $17(57 \%)$ & $13(43 \%)$ \\
\hline
\end{tabular}


chasing behavior in the small tank and Chrysophrys major, Lutjanus rivulatus and $L$. russelli each having the relatively stable schooling habit showed the chasing behavior, but only slightly. Prionurus microlepidotus, Girella punctata, $G$. melanichthys and many fishes of the genus Chaetodon, whose schools were very unstable, displayed the chasing behavior most violently in captivity.

On the other hand, some of the solitary fishes such as eels, moray eels and lion fishes (Pterois) do not show any chasing behavior even in captivity. And in some fishes of the family Serranidae, such as Epinephelus, the chasing behavior seldom occurs. It is very interesting to note that all these fishes are carnivores (Hiatt and Strasburg, 1960) with large mouth or sharp teeth.

\section{Intra- and Interspecific Relations of Fish Chasing in Captivity}

As reported in my previous papers (Okuno, $1962 \mathrm{a}$ and 1963), there are three types of chasing behaviors in the small tank, i.e., intraspecific, nonspecific and interspecific.

1) Intraspecific chasing type: Chasings occur mainly among the individuals of the same species, but scarcely between the individuals of different species.

2) Nonspecific chasing type: Chasings occur among the individuals of the same species as well as between the individuals of different species.

3) Interspecific chasing type: Chasings scarcely occur among the individuals of the same species but mostly are directed to the individuals of other species.

In the following the additional data on the chasing habit of 16 species are given other than 30 species whose chasing behaviors are already reported (OKuno, $1962 \mathrm{a}$ and 1963).

(1) Chasing behaviors of young Girella punctata and G. melanichthys.

Sociograms of chasings occurred among the individuals of young G. punctata and $G$. melanichthys having $918 \mathrm{~cm}$ total length in tanks D (volume: 1601 ), $\mathrm{E}$ (100 1) and $F(501)$ are shown in Table $11 \mathrm{a}-\mathbf{i}$.

G. punctata dominated over $G$. melanichthys in the cases a, c, e, f, g and $\mathrm{i}$ shown in Table 11, while G. melanichthys dominated over the other in other cases. In the former cases, G. punctata chased G. melanichthys as well as the individuals of its own species, and vice versa in the latter cases. Thus, young fishes of these species, at least in the stage less than $18 \mathrm{~cm}$ in total length, chase one another without discriminating the specificity of object individuals.

(2) Chasing behavior displayed between young Girella and other kinds of fishes.

Sociograms of chasings found among young G. punctata and G. melanichthys and other fishes are shown in Tables 12-14. 
Table $11 \mathrm{a}-\mathfrak{i}$. Sociograms of chasings displayed between young Girella punctata and G. melanichthys.

\begin{tabular}{|c|c|c|c|c|c|c|}
\hline $\mathbf{a}$ & Tank F, 100 minutes & & $\begin{array}{l}\text { Total length } \\
\text { in } \mathrm{cm}\end{array}$ & G. punctata & $\begin{array}{l}\text { G. mala- } \\
\text { nichthys }\end{array}$ & $\begin{array}{l}\text { Observed } \\
\text { dates }\end{array}$ \\
\hline & Girella punctata & 4 & $10.8-11.9$ & 438 & 521 & \multirow{2}{*}{ Dec. 1961} \\
\hline & Girella melanichthys & 4 & $10.1-10.8$ & 30 & 90 & \\
\hline \multirow[t]{3}{*}{$\mathbf{b}$} & Tank F, $100 \mathrm{~min}$. & & & & & \\
\hline & G. puntata & 4 & $10.3-11.3$ & 120 & 121 & \multirow{2}{*}{ Dec. 1961} \\
\hline & G. melanichthys & 4 & $9.3-11.0$ & 319 & 224 & \\
\hline \multirow[t]{3}{*}{ c } & \multicolumn{6}{|l|}{ Tank $\mathrm{D}, 100 \mathrm{~min}$} \\
\hline & G. punctata & 4 & $10.8-11.9$ & 431 & 688 & \multirow{2}{*}{ Jan. 1962} \\
\hline & G. melanichthys & 4 & $10.1-10.8$ & 10 & 43 & \\
\hline \multirow[t]{3}{*}{ d } & \multicolumn{6}{|l|}{ Tank E, $100 \mathrm{~min}}$. \\
\hline & G. punctata & 4 & $10.3-11.3$ & 179 & 179 & \multirow{2}{*}{ Jan. 1962} \\
\hline & G. melanichthys & 4 & $9.3-11.0$ & 262 & 436 & \\
\hline \multirow[t]{3}{*}{$\mathbf{e}$} & \multicolumn{6}{|l|}{ Tank F, $100 \mathrm{~min}}$. \\
\hline & G. punctata & 4 & $12.5-13.5$ & 154 & 81 & \multirow{2}{*}{ May 1962} \\
\hline & G. melanichthys & 4 & $12.5-14.0$ & 8 & 15 & \\
\hline \multirow[t]{3}{*}{$\mathbf{f}$} & \multicolumn{6}{|l|}{ Tank F, 100 min. } \\
\hline & G. punctata & 4 & $11.8-13.0$ & 148 & 162 & \multirow{2}{*}{ May 1962} \\
\hline & G. melanichthys & 4 & $11.8-13.0$ & 3 & 28 & \\
\hline \multirow[t]{3}{*}{$\mathbf{g}$} & Tank F, $100 \mathrm{~min}$ & & & & & $\cdots$ \\
\hline & G. punctata & 2 & $9.3,10.0$ & 727 & 1319 & \multirow{2}{*}{ May 1962} \\
\hline & G. melanichthys & 2 & $9.3,10.5$ & 7 & 31 & \\
\hline \multicolumn{7}{|c|}{ h Tank F, 40 min. } \\
\hline & G. punctata & 4 & $11.7-13.1$ & 55 & 26 & \multirow{2}{*}{ May 1962} \\
\hline & G. melanichthys & 4 & $11.5-14.0$ & 109 & 101 & \\
\hline \multirow[t]{3}{*}{ i } & Tank D, $100 \mathrm{~min}$. & & & & & \\
\hline & G. punctata & 2 & $18.2,17.5$ & 77 & 453 & \multirow{2}{*}{ May 1962} \\
\hline & G. melanichthys & 2 & $17.3,17.5$ & 27 & 100 & \\
\hline
\end{tabular}


Table 12 a e. Sociograms of chasings displayed among young G. punctata, young $G$. melanichthys and other fishes.

\begin{tabular}{|c|c|c|c|c|c|c|c|c|c|}
\hline $\mathbf{a}$ & Tank D, 100 min. & & $\begin{array}{l}\text { Total length } \\
\text { in } \mathrm{cm}\end{array}$ & \multicolumn{2}{|c|}{ G. punctata } & \multicolumn{2}{|c|}{$\begin{array}{l}\text { G. mela- } \\
\text { nichthys }\end{array}$} & \multirow{2}{*}{$\begin{array}{l}\text { M. stri- } \\
\text { gatus } \\
\qquad\end{array}$} & $\begin{array}{c}\text { Observed } \\
\text { dates }\end{array}$ \\
\hline & G. punctata & 4 & $10.8-11.9$ & \multicolumn{2}{|c|}{311} & \multicolumn{2}{|c|}{429} & & \multirow{3}{*}{ Jan. 1962} \\
\hline & G. melanichthys & 4 & $10.1-10.8$ & \multicolumn{2}{|c|}{72} & \multicolumn{2}{|c|}{164} & 0 & \\
\hline & Microcanthus strigatus & 4 & $10-12$ & \multicolumn{2}{|c|}{0} & \multicolumn{2}{|c|}{1} & 104 & \\
\hline \multirow[t]{3}{*}{ b } & Tank D, 100 min. & & \multicolumn{3}{|c|}{ G. punctata } & \multicolumn{2}{|c|}{$\begin{array}{l}\text { G. mela: } \\
\text { nichthys }\end{array}$} & \multicolumn{2}{|l|}{$\begin{array}{l}\text { M. stri } \\
\text { gatus }\end{array}$} \\
\hline & G. punctata & 1 & 10.8 & \multicolumn{2}{|c|}{139} & \multicolumn{2}{|c|}{276} & 15 & \multirow[b]{2}{*}{ Jan. 1962} \\
\hline & \multicolumn{7}{|c|}{ (Chasing numbers per one individual to each species) } & 4 & \\
\hline \multicolumn{3}{|c|}{ c Tank $\mathrm{D}, 100 \mathrm{~min}}$. & \multicolumn{7}{|c|}{ G. punctata $\begin{array}{l}\text { G. mela- } \\
\text { nichthys }\end{array}$. mezina $\begin{array}{l}M . \text { stri- } \\
\text { gatus }\end{array}$} \\
\hline & G. punctata & 2 & $10-12$ & & & 344 & 81 & 8 & \multirow{4}{*}{ Feb. 1962} \\
\hline & G. melanichthys & 2 & $10-12$ & & 9 & 102 & 38 & 1 & \\
\hline & G. mezina & 2 & 8,12 & & 6 & 23 & 6 & 1 & \\
\hline & M. strigatus & 2 & $10-12$ & & 0 & 0 & 0 & 297 & \\
\hline \multirow[t]{5}{*}{ d } & Tank F, 100 min. & & \multicolumn{3}{|c|}{ G. punctata } & $\begin{array}{l}\text { mela- } \\
\text { chthys }\end{array}$ & $P$. sp. A & $\begin{array}{l}\text { A. fre- } \\
\text { natus }\end{array}$ & \\
\hline & G. punctata & 2 & $10-12$ & 10 & & 687 & 52 & 0 & \multirow{4}{*}{ May 1962} \\
\hline & G. melanichthys & 2 & $10-12$ & & 9 & 54 & 5 & 0 & \\
\hline & Pomacentrus sp. A & 2 & $7.2,7.0$ & & 0 & 0 & 81 & 0 & \\
\hline & Amphiprion frenatus & 2 & $5.9,4.9$ & & 0 & 0 & 0 & 9 & \\
\hline \multicolumn{3}{|c|}{ e Tank $\mathrm{D}, 100 \mathrm{~min}}$. & \multicolumn{7}{|c|}{$\begin{array}{l}\text { G. punctata G. mela- M. stri- P. micro- } \\
\mathrm{A} \quad \mathrm{B} \text { nichthys gatus lepidotus }\end{array}$} \\
\hline & G. punctata & A & 18.2 & * & 137 & 159 & 0 & 8 & \multirow{5}{*}{ May 1962} \\
\hline & G. punctata & B & 17.5 & 3 & * & 17 & 0 & 0 & \\
\hline & G. melanichthys & 1 & 17.5 & 0 & 0 & $*$ & 0 & 0 & \\
\hline & $M$. strigatus & 1 & 18.0 & 0 & 0 & 0 & $*$ & 16 & \\
\hline & Prionurus microlepidotus & & 19.0 & 2 & 0 & 0 & 0 & $*$ & \\
\hline
\end{tabular}

Table 13 a and $b$. Sociograms of chasings displayed between young G. punctata and other fishes.

\begin{tabular}{|c|c|c|c|c|c|c|c|c|}
\hline \multirow{4}{*}{$\mathbf{a}$} & \multicolumn{2}{|l|}{ Tank F, 100 min. } & \multirow{2}{*}{$\begin{array}{l}\text { Total length } \\
\text { in } \mathrm{cm}\end{array}$} & \multicolumn{2}{|c|}{ G. punctata } & \multicolumn{2}{|c|}{ A. vaigiensis } & \multirow{2}{*}{$\begin{array}{c}\text { Observed } \\
\text { dates }\end{array}$} \\
\hline & & & & & & & & \\
\hline & G. punctata & $\begin{array}{l}\mathrm{A} \\
\mathrm{B}\end{array}$ & $\begin{array}{l}10.9 \\
10.5\end{array}$ & * & $\begin{array}{r}143 \\
*\end{array}$ & $\begin{array}{r}18 \\
0\end{array}$ & $\begin{array}{l}9 \\
0\end{array}$ & \multirow{2}{*}{ May 1962} \\
\hline & Abudefduf vaigiensis & $\begin{array}{l}\mathrm{A} \\
\mathrm{B}\end{array}$ & $\begin{array}{l}4.6 \\
3.4\end{array}$ & $\begin{array}{l}0 \\
0\end{array}$ & $\begin{array}{l}0 \\
0\end{array}$ & $\begin{array}{l}* \\
0\end{array}$ & $\begin{array}{r}75 \\
*\end{array}$ & \\
\hline b & \multicolumn{2}{|l|}{ Tank F, 100 min. } & \multicolumn{3}{|c|}{ G. punctasa } & \multicolumn{2}{|c|}{$P$. sp. A } & \\
\hline & G. punctata & $\begin{array}{l}\mathrm{A} \\
\mathrm{B}\end{array}$ & $\begin{array}{l}10.9 \\
10.5\end{array}$ & $\begin{array}{l}* \\
2\end{array}$ & $\begin{array}{r}42 \\
*\end{array}$ & $\begin{array}{l}8 \\
0\end{array}$ & $\begin{array}{r}14 \\
0\end{array}$ & \multirow{2}{*}{ May 1962} \\
\hline \multicolumn{2}{|r|}{ Pomacentrus sp. A } & $\begin{array}{l}\mathrm{A} \\
\mathrm{B}\end{array}$ & $\begin{array}{l}7.2 \\
7.0\end{array}$ & $\begin{array}{l}0 \\
0\end{array}$ & $\begin{array}{l}0 \\
0\end{array}$ & $\begin{array}{l}* \\
0\end{array}$ & $\begin{array}{r}25 \\
*\end{array}$ & \\
\hline
\end{tabular}


Table $14 \mathrm{a}-\mathrm{i}$. Sociograms of chasings displayed between young G. melanichthys and other fishes.

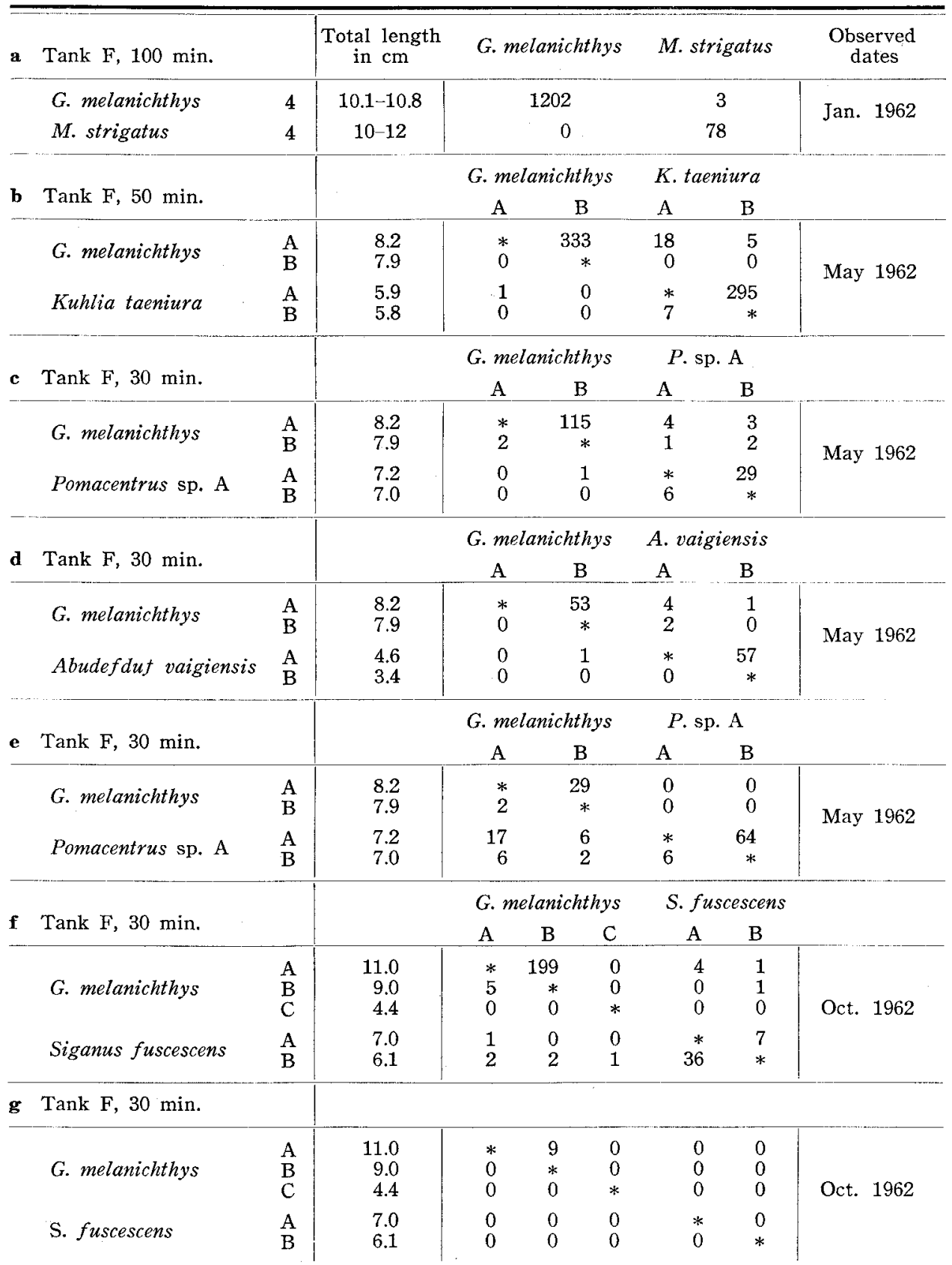


Table 14 (continued)

\begin{tabular}{|c|c|c|c|c|c|c|c|c|c|}
\hline \multirow{2}{*}{ h } & \multirow{2}{*}{ Tank F, 30 min. } & \multirow[b]{3}{*}{$\begin{array}{l}A \\
B \\
C\end{array}$} & & \multicolumn{3}{|c|}{ G. melanichthys } & \multicolumn{2}{|c|}{ S. fuscescens } & \\
\hline & & & & $\mathrm{A}$ & $\mathrm{B}$ & C & $\mathrm{A}$ & B & \\
\hline & G. melanichthys & & $\begin{array}{r}11.0 \\
9.0 \\
4.4\end{array}$ & $\begin{array}{l}* \\
0 \\
0\end{array}$ & $\begin{array}{r}630 \\
* \\
0\end{array}$ & $\begin{array}{r}28 \\
0 \\
*\end{array}$ & $\begin{array}{l}3 \\
0 \\
0\end{array}$ & $\begin{array}{l}3 \\
0 \\
0\end{array}$ & \multirow[t]{2}{*}{ Oct. 1962} \\
\hline & S. fuscescens & $\begin{array}{l}\text { A } \\
\text { B }\end{array}$ & $\begin{array}{l}7.0 \\
6.1\end{array}$ & $\begin{array}{l}0 \\
0\end{array}$ & $\begin{array}{l}0 \\
0\end{array}$ & $\begin{array}{l}0 \\
0\end{array}$ & $*$ & $\begin{array}{l}0 \\
*\end{array}$ & \\
\hline i & Tank F, 100 min. & & \multicolumn{3}{|c|}{$\begin{array}{l}\text { G. mela- } \\
\text { nichthys }\end{array}$} & $\begin{array}{l}M . \text { stri- } \\
\text { gatus }\end{array}$ & \multicolumn{2}{|c|}{$\begin{array}{l}\text { P. micro- } \\
\text { lepidotus }\end{array}$} & \\
\hline & G. melanichthys & 4 & $9-10$ & \multicolumn{2}{|c|}{687} & 2 & \multicolumn{2}{|c|}{0} & \\
\hline & M. strigatus & 4 & 10 & \multicolumn{2}{|c|}{0} & 354 & \multicolumn{2}{|c|}{1} & Jan. 1962 \\
\hline & P. microlepidotus & 1 & 10 & \multicolumn{2}{|c|}{0} & 1 & \multicolumn{2}{|c|}{$*$} & \\
\hline
\end{tabular}

As shown in Table $12 \mathrm{a}-\mathrm{e}$, young fishes of these two species of Girella seldom chase fishes of other species such as Microcanthus strigatus, Pomacentrus sp. A. Amphiprion frenatus and Prionurus microlepidotus, although they display violent chasing among the individuals of these two species. It is a very interesting fact that as to the exceptional cases of chasing G. punctata chased Pomacentrus sp. A more frequently than Amphiprion frenatus or Abudefduf vaigiensis as shown in Tables $12 \mathrm{~d}$ and $13 \mathrm{a}$ and $\mathrm{b}$. Pomacentrus sp. A resembles G. punctata in shape and color, whereas Amphiprion frenatus and Abudefduf vaigiensis have the appearance entirely different from that of $G$. punctata.

On the other hand, it is worthy to be noted that $G$. melanichthys scarcely chases Siganus fuscescens which sometimes joins to the schools of the former in natural environments (OKuno, $1962 \mathrm{~b}$ ). A consideration on these phenomena will be given later.

(3) Chasing behavior displayed between young G. mezina and other fishes.

A few data were obtained about the chasing habit of young G. mezina. The data presented in Tables $12 \mathrm{c}$ and 15 seem to show that young G. mezina chases other individuals of the same species as well as those other two species of Girella without discriminating the specific difference but scarcely chase other kinds of fishes such as $M$. strigatus or A. vaigiensis.

Table 15. Sociograms of chasings displayed between young Girella mezina and Abudefduf vaigiensis.

\begin{tabular}{|c|c|c|c|c|c|c|c|}
\hline \multirow{2}{*}{ Tank F, 30 min. } & & \multirow{2}{*}{$\begin{array}{l}\text { Total ledgth } \\
\text { in } \mathrm{cm}\end{array}$} & \multicolumn{2}{|c|}{ G. mezina } & \multicolumn{2}{|c|}{ A. vaigiensis } & \multirow{2}{*}{$\begin{array}{l}\text { Observed } \\
\text { date }\end{array}$} \\
\hline & & & $\mathrm{A}$ & $\mathrm{B}$ & $\mathrm{A}$ & $\mathrm{B}$ & \\
\hline G. mezina & $\begin{array}{l}\mathrm{A} \\
\mathrm{B}\end{array}$ & $\begin{array}{r}12 \\
8\end{array}$ & $\begin{array}{l}* \\
0\end{array}$ & $\begin{array}{r}34 \\
*\end{array}$ & $\begin{array}{l}5 \\
3\end{array}$ & $\begin{array}{l}2 \\
0\end{array}$ & \multirow{2}{*}{ May 1962} \\
\hline Abudefduf vaigiensis & $\begin{array}{l}\mathrm{A} \\
\mathrm{B}\end{array}$ & $\begin{array}{l}4.6 \\
3.4\end{array}$ & $\begin{array}{l}0 \\
0\end{array}$ & $\begin{array}{l}1 \\
0\end{array}$ & $\begin{array}{l}* \\
0\end{array}$ & $\begin{array}{r}79 \\
*\end{array}$ & \\
\hline
\end{tabular}


(4) Chasing behaviors of adult G. punctata and G. melanichthys.

Contrary to the cases of young Girella, adult G. punctata and G. melanichthys chase each other very rarely as seen clearly in Table 16 a.

Table 16 a and b. Sociograms of chasings displayed among adult Girella punctata and G. melanichthys and other fishes. (a : after OKuno, 1963)

\begin{tabular}{|c|c|c|c|c|c|c|c|c|c|c|c|}
\hline $\mathbf{a}$ & Tank A, $120 \mathrm{~min}$. & & $\begin{array}{l}\text { Total } \\
\text { length } \\
\text { in } \mathrm{cm}\end{array}$ & 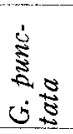 & 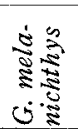 & 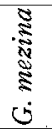 & (ब) & 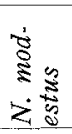 & \begin{tabular}{l}
$\dot{3}$ \\
\multirow{3}{8}{} \\
$\dot{8}$ \\
$\dot{8}$
\end{tabular} & $\frac{\dot{s}}{\dot{s} \frac{3}{s}}$ & $\begin{array}{l}\text { Observed } \\
\text { date }\end{array}$ \\
\hline & Girella punctata & 4 & $28-30$ & 104 & 13 & 2 & 0 & 0 & 0 & 0 & \multirow{7}{*}{ Dec. 1961} \\
\hline & G. melanichthys & 5 & $18-32$ & 4 & 180 & 32 & 1 & 0 & 0 & 0 & \\
\hline & G. mezina & 4 & $12-23$ & 0 & 3 & 5 & 0 & 0 & 0 & 0 & \\
\hline & Stephanolepis cirrhifer & 9 & $15-18$ & 0 & 0 & 0 & 91 & 2 & 2 & 0 & \\
\hline & Navodon modestus & 2 & 30 & 0 & 0 & 0 & 1 & 5 & 0 & 0 & \\
\hline & Siganus fuscescens & 3 & $25-30$ & 0 & 0 & 0 & 0 & 0 & 74 & 0 & \\
\hline & Arothron hispidus & 2 & 10 & 0 & 0 & 0 & 0 & 0 & 0 & 8 & \\
\hline \multirow[t]{8}{*}{ b } & Tank A, $100 \mathrm{~min}$. & & & 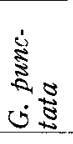 & 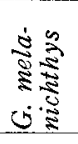 & 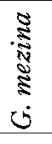 & $\begin{array}{l}\dot{s} \\
3 \\
\dot{8} \\
\dot{8} \\
\dot{8}\end{array}$ & 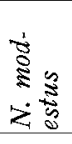 & 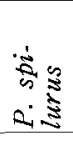 & $\frac{2}{20}$ & \\
\hline & G. punctata & 2 & $28-30$ & 62 & 23 & 4 & 1 & 0 & 0 & 0 & \multirow{7}{*}{ June 1962} \\
\hline & G. melanichthys & 4 & $20-32$ & 10 & 170 & 6 & 0 & 0 & 0 & 0 & \\
\hline & G. mezina & 4 & $12-23$ & 0 & 10 & 26 & 0 & 0 & 0 & 0 & \\
\hline & S. fuscescens & 4 & $25-30$ & 0 & 1 & 5 & 199 & 0 & 0 & 0 & \\
\hline & N. modestus & 3 & 30 & 0 & 1 & 0 & 0 & 39 & 0 & 0 & \\
\hline & Pseudupeneus spilurus & 1 & 30 & 0 & 0 & 0 & 0 & 0 & $*$ & 0 & \\
\hline & A. hispidus & 2 & 10 & 0 & 0 & 0 & 0 & 0 & 0 & 0 & \\
\hline
\end{tabular}

However, in another case shown in Table $16 \mathrm{~b}$, G. punctata chased G. melanichthys more frequently than in the case shown in a of the table. In this tank, an individual of $G$. punctata with $30 \mathrm{~cm}$ total length dominated perfectly over another $28 \mathrm{~cm}$ long individual of the same species and also over four individuals of $G$. melanichthys, while the subordinate individuals of $G$. punctata seldom chased $G$. melanichthys. Therefore, all 62 chasings between the two individuals of $G$. punctata and nearly all of 23 chasings of $G$. punctata to G. melanichthys are considered apparently to be done by that dominant individual of G. punctata. Anyhow, the average number of chasings addressed to each individual of $G$. melanichthys is only six. Thus, also in this case, it is certain that the dominant individual of $G$. punctata did not chase $G$. melanichthys so frequently as it did to its subordinate. After all, it may be concluded that the chasing is displayed among three species of Girella much more frequently than between those and other kinds of fishes. 
(5) Chasing behaviors displayed among seven species of the suborder Pomacentrina.

Results of the observations on the chasing behaviors of seven species of the suborder Pomacentrina or damsel fishes are shown in Table 17 a-1. Here six cases of nonspecific type and one of intraspecific type are discernible.

Three species of Pomacentrus: As shown in Table $17 \mathrm{a}$, pomacentrus coelestis displays interspecific chasings as well as intraspecific ones. Thus, P. coelestis can be regarded to belong to the nonspecific chasing type. Pomacentrus sp. B also chases the same species as well as those of other species without discriminating any specific differences as shown in Table $17 \mathrm{a}, \mathrm{b}$ and c. The type of Pomacentrus sp. A is, however, rather indistinct as shown in Tables 171 and $14 \mathrm{e}$. This

Table 17 a-1. Sociograms of chasings displayed among seven species of pomacentrid fishes.

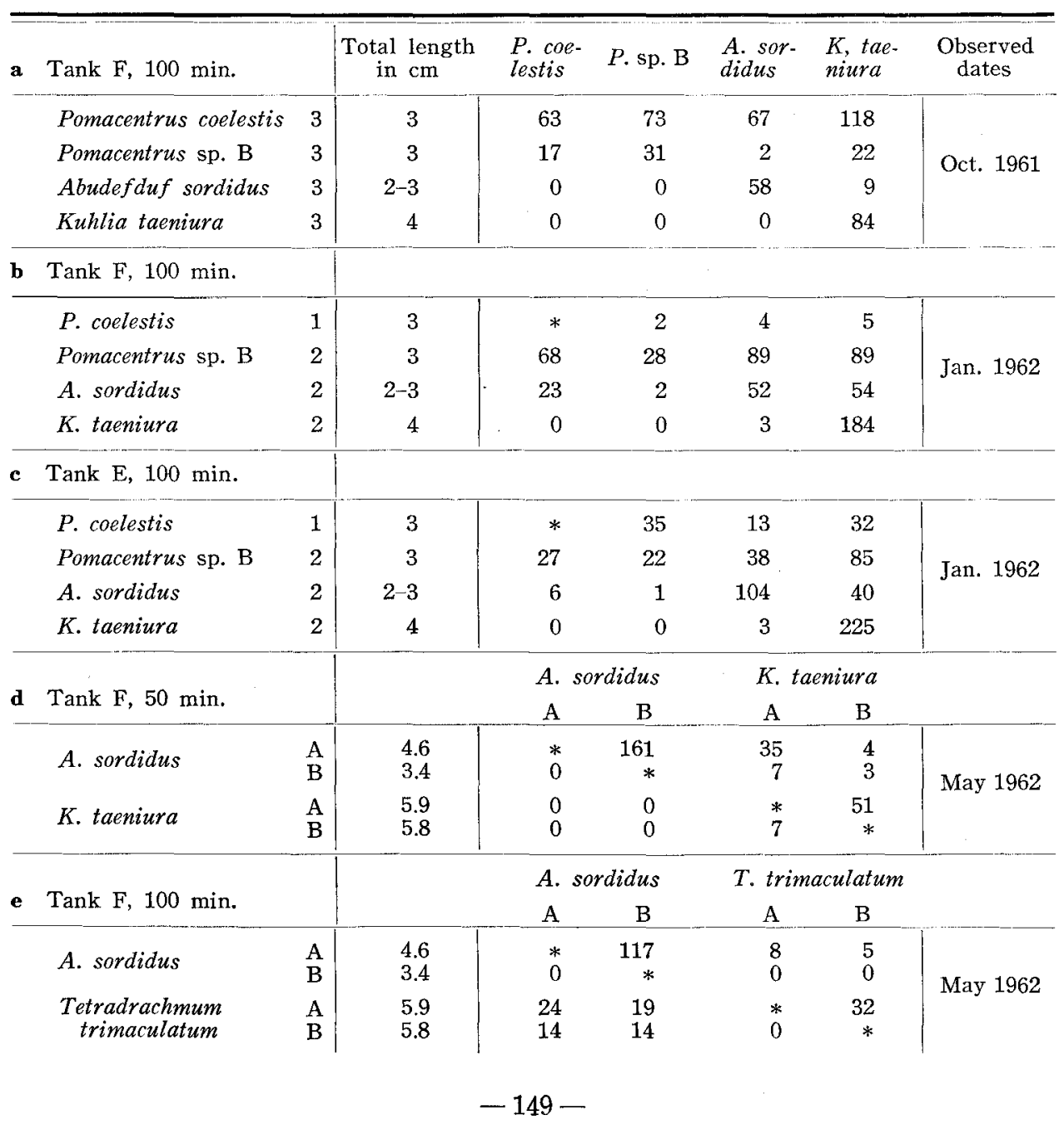


Table 17 (continued)

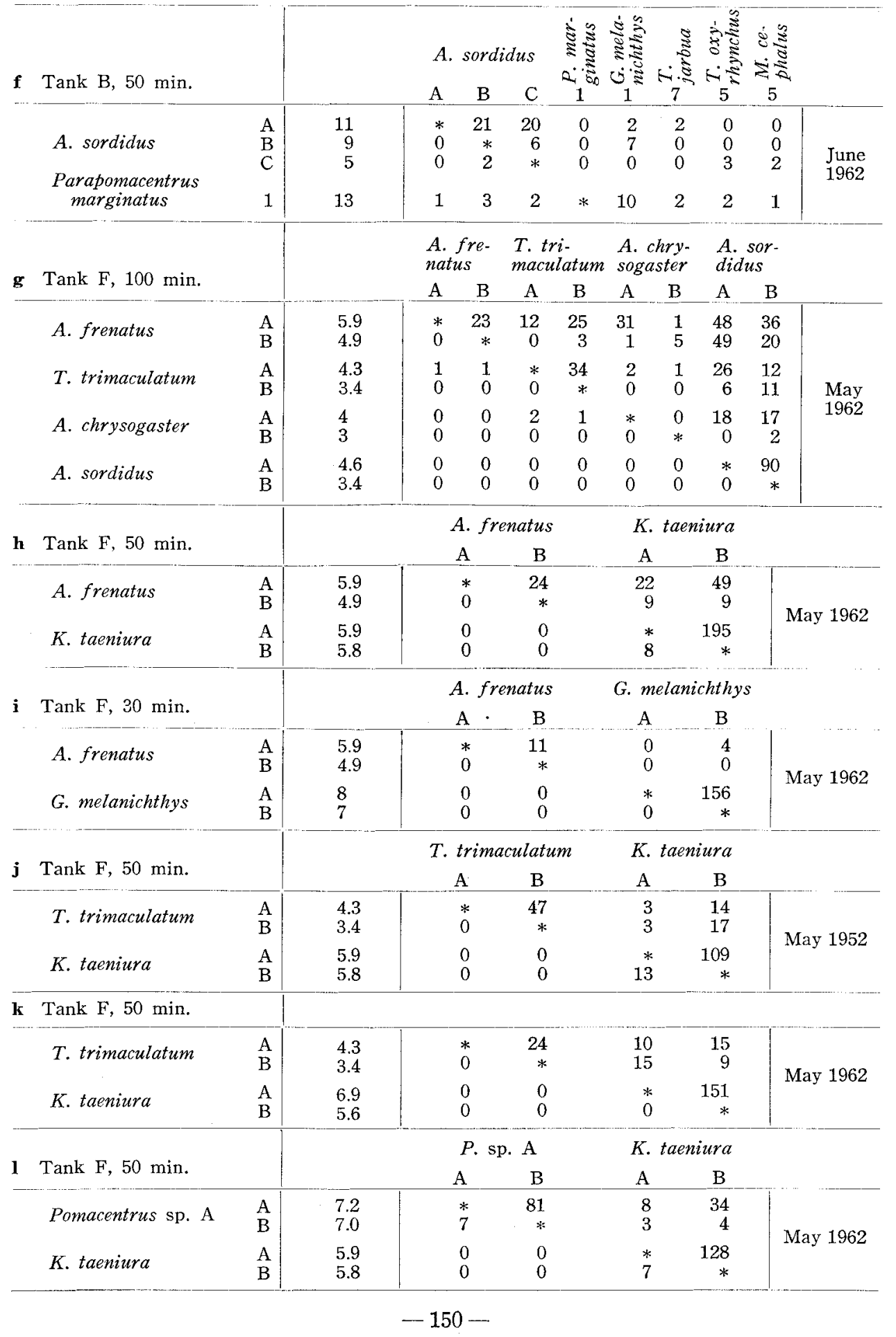


species might be of an intermediate type or rather of nonspecific type. In other experiments shown in Tables $12 \mathrm{~d}, 13 \mathrm{~b}$, and $14 \mathrm{c}$, this species did not chase any other species. Very probably this is due to the existence of other overwhelming dominant species in those cases as in the case reported on Tetradrachmum trimaculatum (Okuno, 1963).

Two species of Amphiprion: Amphiprion frenatus belongs obviously to the nonspecific type as seen clearly in the data of Tables $17 \mathrm{~g}, \mathrm{~h}$ and $\mathrm{i}$. The dominant individual of this species chases the fishes of other species as well as his subordinates. Amphiprion chrysogaster is ever assigned to the nonspecific type (OKuno, 1963), but in the test shown in Table $17 \mathrm{~g}$ the dominant individual of this species did not chase his subordinate but T. trimaculatum and A. sordidus. Abudefduf sordidus: Seven observations were made on Abudefduf sordidus as shown in Table $17 \mathrm{a}-\mathrm{g}$. In one case (Table $17 \mathrm{~g}$ ) this species was at the lowest hierarchial rank in that tank. In five of the rest six, the species showed a trend to the intraspecific chasing type, while in the remaining single case it seemed to display the chasing of nonspecific type (Table $17 \mathrm{e}$ ). This species chases other fishes of the intraspecific type do, but probably this belong to the intraspecific type as already reported (OKUNO, 1963).

Tetradrachmum trimaculatum: The chasing behavior of T. trimaculatum is already reported in my previous paper (OKUno, 1963), and the nonspecific type of its chasing habit was a certained again in four observations shown in Tables $17 \mathrm{e}$, $\mathrm{g}$, $\mathrm{j}$ and $\mathrm{k}$.

(6) Chasing behaviors of the fishes of the suborder Chaetodontina.

Chasing behaviors of nine species of chaetodont fishes are considered to be of the intraspecific type in my previous papers (OKuno, $1962 \mathrm{a}$ and 1963). In addition, data on three species are presented here in Table $18 \mathrm{a}-\mathrm{c}$.

Forcipiger longirostris: The observation was made in the $1.5 \mathrm{~m}^{3} \operatorname{tank}$, the results are shown in Table $18 \mathrm{a}$. The dominant individual of this species chased its subordinate exclusively, although it was reared together with 29 individuals of other 14 species of chaetodont fishes. Thus, this species evidently belongs to intraspecific type.

Monodactylus argenteus and Scatophagus argus: Five individuals of the former and four of the latter were reared together in a tank. Chasings occurred exclusively among individuals of the same species as seen in Table $18 \mathrm{~b}$. Thus these two species are safely regarded as being of the intraspecific type.

Microcanthus strigatus: The chasing type of this species is described already as intraspecific (OKuno, 1963). The same conclusion was gained in the present study on the data given in Tables $12 \mathrm{a}, \mathrm{c}, \mathrm{e}, 14 \mathrm{a}, \mathrm{i}$ and $18 \mathrm{c}$.

Other species of Chaetodontidae: In July 1962, 150 coral fishes belonging to 50 species were carried by members of Suma Aquarium from Amami to the aquarium at Kobe in two tanks of $1.5 \mathrm{~m}$ long, $0.8 \mathrm{~m}$ wide and $1 \mathrm{~m}$ deep on a 
Table 18 a-c. Sociograms of chasings displayed by chaetodont fishes.

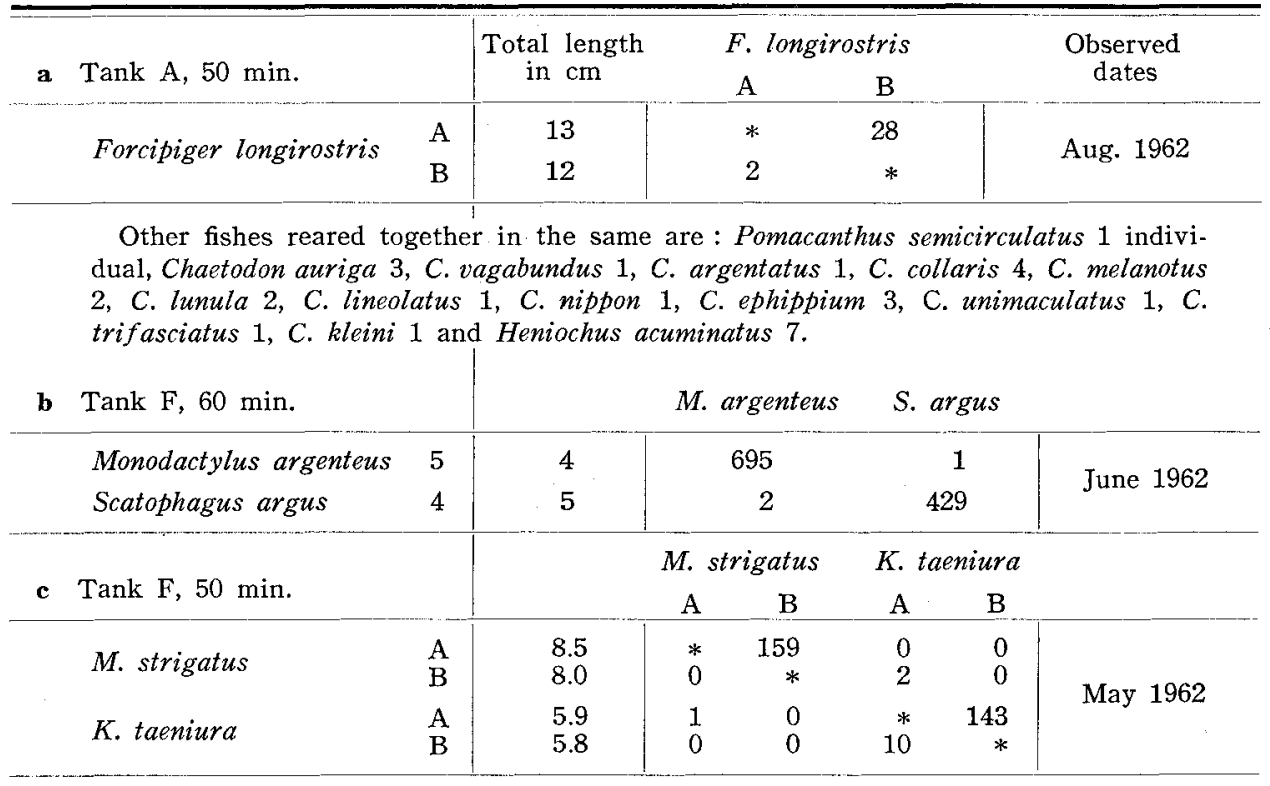

liner sailing between Okinawa and Kobe. And I had chances to observe in these tanks the chasing behaviors of some coral reef fishes, although I failed to make sociograms of the chasings. It is supposed that adults of Chaetodon argentatus, C. citrinellus, C. unimaculatus and C. trifasciatus display the chasing of intraspecific type.

Okuno, Kurio and Nishiguchi (1960) served that individuals of Pomacanthus semicirculatus in a $1.5 \mathrm{~m}^{3}$ tank defended their territories by chasing other chaetodont species as well as other individuals of the same species. Thus it is supposed that the chasing of $P$. semicirculatus is of the nonspecific type.

(7) Chasing behavior of Apogon doederleini.

Result of the observation on the chasing displayed between A. doederleini and A. notatus is shown in Table 19. The chasing behavior of A. doederleini is

Table 19. Sociogram of chasings displayed between Apogon doederleini and $A$. notatus.

\begin{tabular}{|c|c|c|c|c|c|c|c|c|c|}
\hline \multirow{2}{*}{ Tank F, 50 min. } & & \multirow{2}{*}{$\begin{array}{l}\text { Total } \\
\text { length } \\
\text { in } \mathrm{cm}\end{array}$} & \multicolumn{2}{|c|}{ A. doederleini } & \multicolumn{2}{|c|}{ A. notatus } & \multicolumn{2}{|c|}{ S. inermis } & \multirow{2}{*}{$\begin{array}{c}\text { Observed } \\
\text { date }\end{array}$} \\
\hline & & & $\mathrm{A}$ & $\mathrm{B}$ & A & $\mathrm{B}$ & $\mathrm{A}$ & B & \\
\hline Apogon doederleini & $\begin{array}{l}\mathrm{A} \\
\mathrm{B}\end{array}$ & $\begin{array}{l}10 \\
10\end{array}$ & $\begin{array}{l}* \\
0\end{array}$ & $\begin{array}{r}51 \\
*\end{array}$ & $\begin{array}{l}2 \\
2\end{array}$ & $\begin{array}{l}0 \\
3\end{array}$ & $\begin{array}{l}1 \\
1\end{array}$ & $\begin{array}{l}0 \\
0\end{array}$ & \multirow{3}{*}{ June 1962} \\
\hline A. notatus & $\begin{array}{l}\mathrm{A} \\
\mathrm{B}\end{array}$ & $\begin{array}{l}9 \\
9\end{array}$ & $\begin{array}{l}0 \\
0\end{array}$ & $\begin{array}{l}1 \\
0\end{array}$ & $\begin{array}{l}* \\
0\end{array}$ & $\begin{array}{l}1 \\
*\end{array}$ & $\begin{array}{l}0 \\
0\end{array}$ & $\begin{array}{l}0 \\
0\end{array}$ & \\
\hline Sebastes inermis & $\begin{array}{l}\mathrm{A} \\
\mathrm{B}\end{array}$ & $\begin{array}{l}5 \\
5\end{array}$ & $\begin{array}{l}0 \\
0\end{array}$ & $\begin{array}{l}0 \\
0\end{array}$ & $\begin{array}{l}0 \\
0\end{array}$ & $\begin{array}{l}0 \\
0\end{array}$ & $\begin{array}{l}* \\
0\end{array}$ & $\begin{array}{l}8 \\
*\end{array}$ & \\
\hline
\end{tabular}


evidently of the intraspecific type. However, the type of the chasing displayed by $A$. notatus is unsettled as the chasing of this fish was observed only two times.

(8) Chasing behavior of young Stephanolepis cirrhifer.

The chasing behaviors of young individuals of $S$. cirrhifer are summarized in Table $20 \mathrm{a}$ and $\mathrm{b}$. The chasing of this fish is of the intraspecific type. Adults of this fish is also considered to be of the intraspecific type (OKuno, 1963).

Table $20 \mathrm{a}$ and b. Sociograms of chasings displayed between Stephanolepis cirrhifer and other fishes.

\begin{tabular}{|c|c|c|c|c|c|c|c|c|c|c|}
\hline \multirow[b]{2}{*}{$\mathbf{a}$} & \multirow{2}{*}{\multicolumn{2}{|c|}{ Tank $F, 30 \mathrm{~min}}}$. & \multirow{2}{*}{$\begin{array}{l}\text { Total } \\
\text { length } \\
\text { in } \mathrm{cm}\end{array}$} & \multicolumn{4}{|c|}{ S. cirrhifer } & \multicolumn{2}{|c|}{$R$. ercodes } & \multirow{2}{*}{$\begin{array}{c}\text { Observed } \\
\text { dates }\end{array}$} \\
\hline & & & & $\mathrm{A}$ & B & $\mathrm{C}$ & & A & $\mathrm{B}$ & \\
\hline & \multirow{3}{*}{ Stephanolepis cirrhifer } & A & 6.2 & $*$ & 29 & 2 & & 0 & 0 & \multirow{5}{*}{ Sep. 1962} \\
\hline & & $\mathrm{B}$ & 5.7 & 0 & $*$ & & & 0 & 0 & \\
\hline & & $\mathrm{C}$ & 4.6 & 0 & 0 & & & 0 & 0 & \\
\hline & \multirow{2}{*}{ Rudarius ercodes } & A & 3.5 & 0 & 0 & \multirow{2}{*}{\multicolumn{2}{|c|}{$\begin{array}{l}0 \\
0\end{array}$}} & * & 1 & \\
\hline & & $\mathbf{B}$ & 3.4 & 0 & 0 & & & 0 & $*$ & \\
\hline \multirow{8}{*}{ b } & \multirow{2}{*}{\multicolumn{2}{|c|}{ Tank F, $30 \mathrm{~min}$. }} & & \multicolumn{2}{|c|}{ S. cirrhifer } & \multicolumn{2}{|c|}{ O. fasciatus } & \multicolumn{2}{|c|}{ S. fuscescen } & \\
\hline & & & & A & B & A & $\mathrm{B}$ & A & B & \\
\hline & S cirrhifer & A & 6.2 & * & 59 & 4 & 1 & 1 & 0 & \multirow{6}{*}{ Sep. 1962} \\
\hline & & B & 5.7 & 0 & $*$ & 0 & 1 & 0 & 0 & \\
\hline & Oplegnathus fasciatus & $\mathrm{A}$ & 10.5 & 0 & 0 & * & 0 & 1 & 0 & \\
\hline & & B & 9.3 & 1 & 3 & 0 & $*$ & 3 & 0 & \\
\hline & \multirow{2}{*}{ S. fuscescens } & A & 6.8 & 0 & 0 & 0 & 1 & $*$ & 110 & \\
\hline & & B & 6.2 & 0 & 0 & 0 & 0 & 0 & * & \\
\hline
\end{tabular}

(9) Chasing behavior of Oplegnathus fasciatus.

Observations on the chasing behavior of this fish were repeated ten times as the results are shown in Table $21 \mathrm{a}-\mathrm{j}$.

Practically no intraspecific chasing was observed among the four individuals of $O$. fasciatus in the first two experiments (Table $21 \mathrm{a}$ and $\mathrm{b}$ ). When they are reared together with other fishes such as $K$. taeniura, S. cirrhifer, S. fuscescens and G. melanichthys (Tables $20 \mathrm{~b}$ and $21 \mathrm{c}-\mathrm{g}$ ), they sometimes chase other species, but without chasing individuals of the same species except for a few cases shown in Table $21 \mathrm{c}$. These results seem to indicate that the chasing of $O$. fasciatus is directed exclusively to the fishes of other species but not to individual of the same species, namely the chasing habit of this species is of the interspecific type.

Occasionally, it was observed in the big tank that subadults of this fish with approximately $20 \mathrm{~cm}$ total length were biting the injured tail of the ray, Dasyatis akajei. This let me have the question if the chasing habit of this fish is not of a social character but of a feeding behavior. Thus, the observations were made preliminarily on young individuals of this species (Table $21 \mathrm{~h}-\mathrm{j}$ ). 
Table $21 \mathrm{a}-\mathrm{j}$. Sociograms of intraspecific chasing of Oplegnathus fasciatus (a and b) and of interspecific chasing displayed between this and others $(c-j)$.

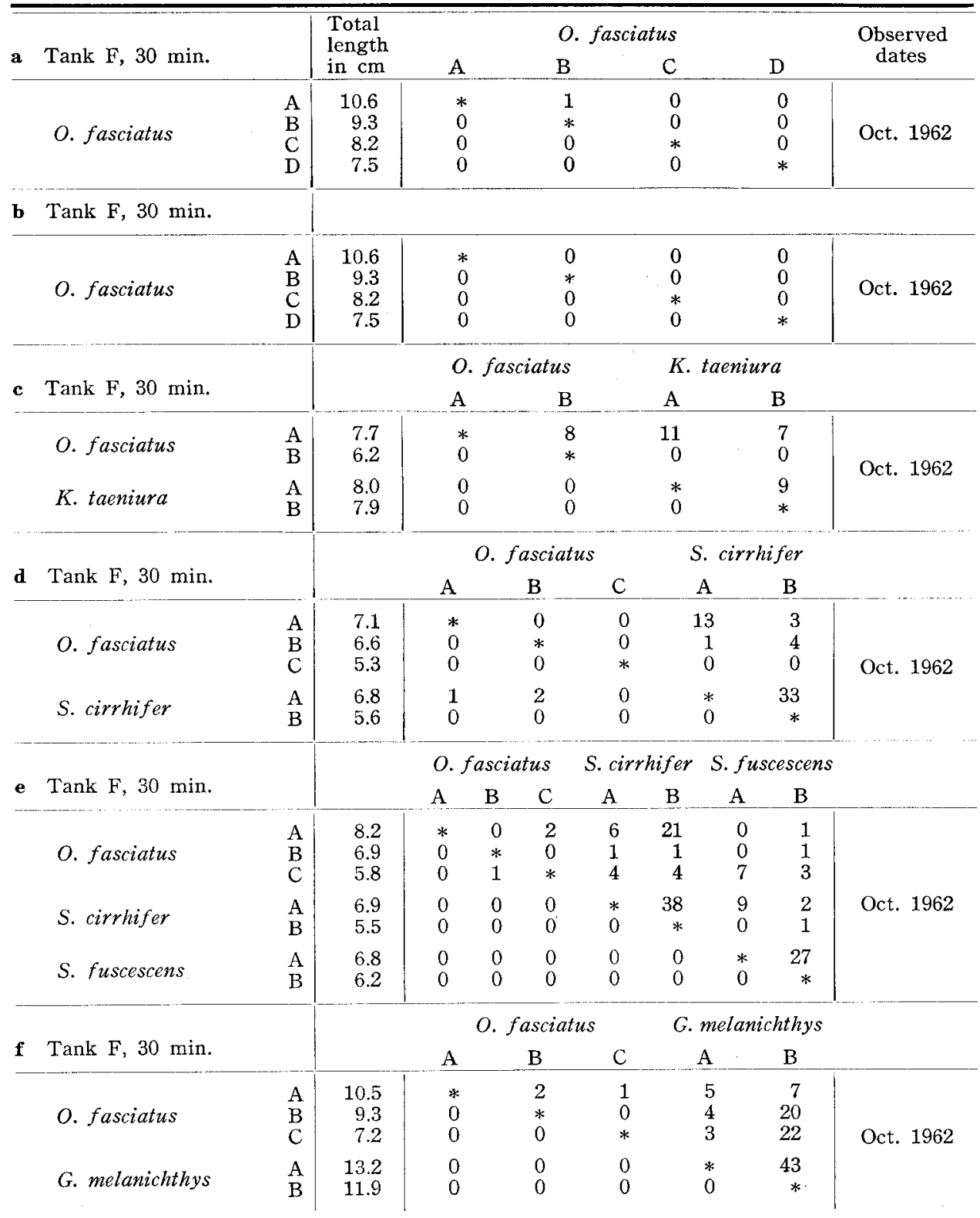


Table 21 (continued)

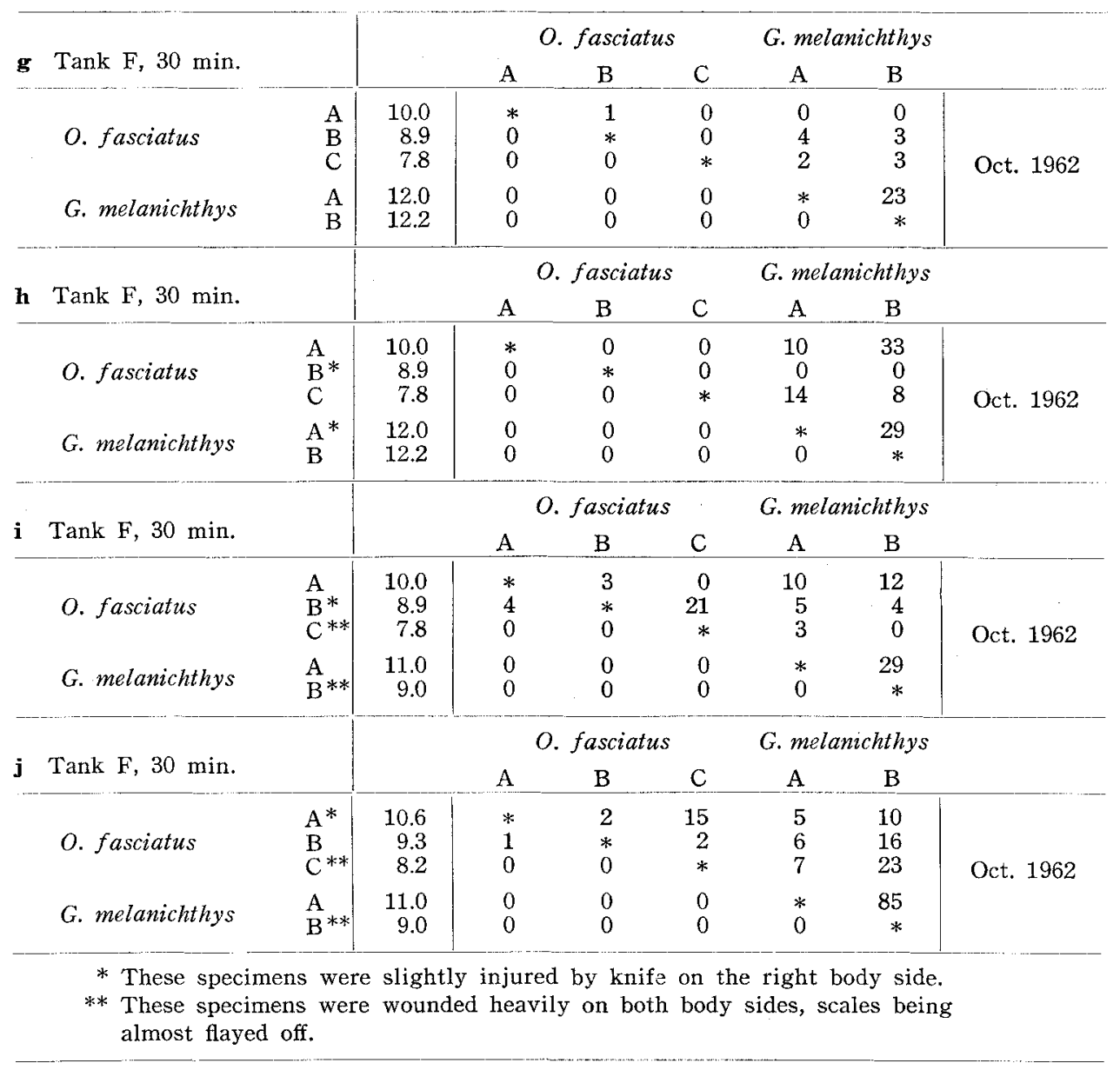

In the first observation (Table $21 \mathrm{~h}$ ), individual B of $O$. fasciatus and individual $\mathrm{A}$ of $G$. melanichthys were slightly injured to attract the biting of healthy $O$. fasciatus, but no effects were recognized. In the second and third cases (Table $21 \mathrm{i}$ and $\mathrm{j}$ ), individual $\mathrm{C}$ of $O$. fasciatus and $\mathrm{B}$ of $G$. melanichthys were heavily injured on body sides. Here, an obvious tendency was seen that chasings of two healthy individuals of $O$. fasciatus were concentrated to the heavily injured individual of $O$. fasciatus as well as to that of G. melanichthys. These results seem to reinforce the above-mentioned assumption. However, I don't believe that these experiments are perfect and enough to deduce any definite conclusion, more crucial researches are desirable.

(10) Other fishes.

The chasing behavior displayed by young fishes of Siganus fuscescens is 
considered to be of the intraspecific type, as be read in Tables $14 \mathrm{f}, 20 \mathrm{~b}$ and $21 \mathrm{e}$. The chasing type of adult fish is certainly intraspecific (OKuno, 1963).

Young fish of Sebastes inermis was found exhibiting only intraspecific chasings in a test shown in Table 19.

The intraspecific chasing type of Kuhlia taeniura (OKuno, 1963) was ascertained again in the present study (Tables $14 \mathrm{~b}, 17 \mathrm{a}, \mathrm{b}, \mathrm{c}, \mathrm{d}, \mathrm{h}, \mathrm{j}, \mathrm{k}$ and $\mathrm{l}, 18 \mathrm{c}$ and $21 \mathrm{c}$ ).

\section{Discussion}

Social Behaviors of Fishes in the Small Tank contra Those in Their Natural Habitats

Correlations between the social behaviors in the sea and those in the tank may be read on Table 22 about 52 species of marine fishes.

(1) Schooling fishes.

Of 52 species listed in Table 22, 33 are schooling fishes. Five of these 33 species have never displayed any chasing in captivity, while other 27 species are found showing the chasing behavior of the intraspecific type in captivity, and the remaining one, Oplegnathus fasciatus, seems to display the chasing of the interspecific type, although the results of some tests allude the possibility that the chasing of this fish is not of a social nature but is related closely to predation. Thus the schooling fishes are generally said to display the chasing of the intraspecific type when the behavior is shown in captivity.

(2) Assembling fishes.

Most of pomacentrid fishes are found forming assemblages in the sea and in captivity they display the chasing of nonspecific type without any exception. Abudefduf sordidus is the only one having the schooling habit among the pomacentrid fishes studied here, although its school is very unstable. In captivity, this fish displays the chasing of the intraspecific type.

(3) Solitary fishes.

There are two types of solitary fishes, hovering solitary and residing solitary. Some of the residing solitary fishes, such as Lethrinus nematacanthus, Tridentiger trigonocephalus and Pomacanthus semicirculatus, show the nonspecific chasing behavior.

It is very probable in both the solitary and grouping fishes that the hovering species are apt to display the chasing of the intraspecific type, while the residing ones have a trend to show the chasing of the nonspecific type when this behavior to exhibited in captivity. 
Table 22. Behavior types of 52 species of marine fishes in the sea or in tanks.

Behavior types in the sea : $\mathbf{A}$ solitary, assemblage, 1 stable school and unstable scnool. Chasing types in tanks : $\times$ no chasing, $\boldsymbol{D}$ intraspecific, nonspecific and $\boldsymbol{A}$ interspecific types. $O \cdot{ }_{j}:$ Types of these cases could not be decided clearly or be observed directly.

\begin{tabular}{|c|c|c|c|}
\hline Name of fish & $\begin{array}{l}\text { Behavior type } \\
\text { in the sea }\end{array}$ & $\begin{array}{l}\text { Behavior type } \\
\text { in the big tank }\end{array}$ & $\begin{array}{l}\text { Chasing type } \\
\text { in small tanks }\end{array}$ \\
\hline 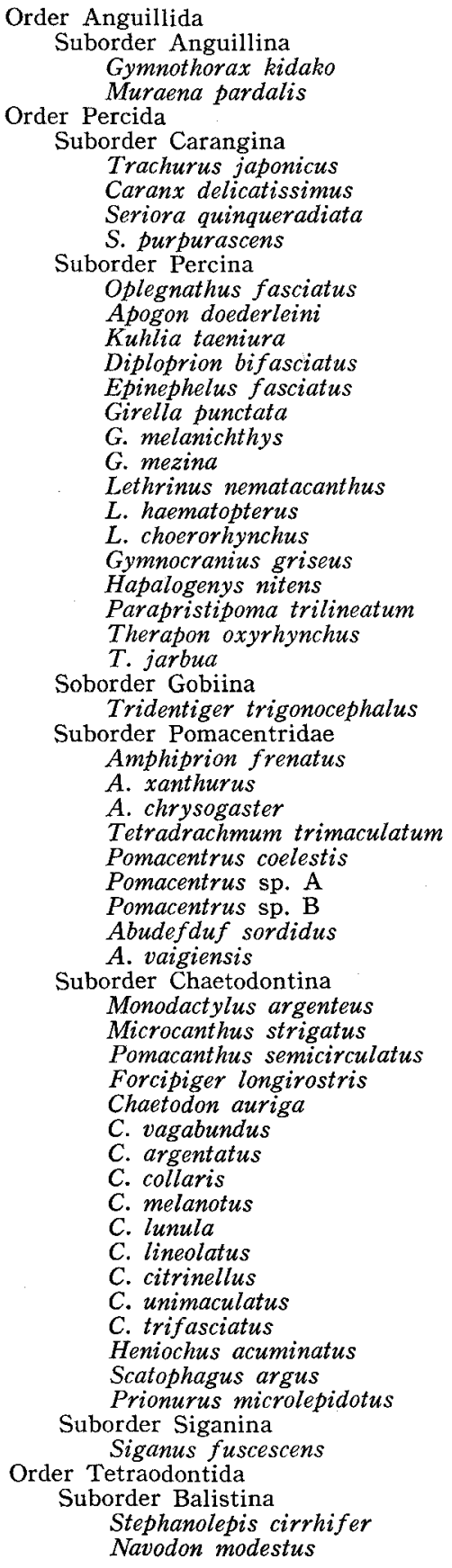 & 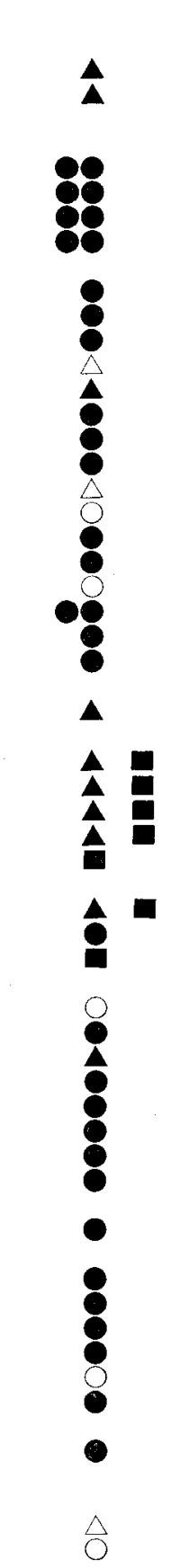 & $\mathbf{\Delta}$ & $\begin{array}{l}x \\
x \\
x \\
x\end{array}$ \\
\hline
\end{tabular}


(4) Relations between the behavior types in captivity and those in natural habitats.

Many fishes in small tanks exhibit the social behaviors different from those in natural habitats. And there are found some relationships between their behaviors in the sea and the aquarium.

In the big tank, the changes of behavior are quite insignificant and there are recognized the social behaviors similar to those in the sea. While in the small tank, the following newly established tendencies are discernible:

1) Stable schooling fishes do not display any chasing,

2) fishes of unstable schooling habit display the chasing of the intraspecific type,

3) the chasing of assembling fishes belongs to the nonspecific type,

4) some of the solitary carnivores never exhibit the chasing behavior, and,

5) solitary fishes of gentle nature display the chasing of the intra- or nonspecific type.

The most important trend discovered during the present study is that the chasing of schooling fishes in captivity belongs to the intraspecific type and that of assembling fishes belongs to the nonspecific type.

One of the characteristics of assembling fishes is that they are associated with or bound to certain places in the sea. Therefore, individuals of each fishes must have some social relations with neighboring other species through "inhabiting areas", as well as they have intraspecific social relations.

The schooling fishes, on the other hand, are not bound to any limited places but hovering about in a wide range. Thus the social relations found among individuals of schooling fishes are mainly of the intraspecific type, and these fishes seldom bear any social relations to other species through their inhabiting places.

Judging from the facts mentioned above, the chasings in captivity seem to occur between the individuals which are bound one another by some social relations, attractive or repulsive, in natural habitats. Namely, schooling fishes display only the chasing of the intraspecific type in captivity, because they have scarcely any social relations to other species in natural environments. While, assembling fishes exhibit the chasing behavior of the nonspecific type, since they have some social relations to other species through their inhabiting areas in natural habitats. Intraspecific chasings found in the schooling or assembling fishes might be based on the attractive relation found among the individuals of these fishes in natural environments, while interspecific chasing in assembling fishes might be based on the repulsive relation, although superficially no difference can be seen between the chasing behaviors in captivity in these two cases.

It is generally suspected that certain repulsive forces or tendencies exist 
among individuals of any one species. In natural environments, such repulsive forces are expressed in a latent state in the schooling or assembling fishes, because they are living in groups. In a limited space, however, the repulsive tendencies among individuals might be released from a latent state and make individuals chase one another. It may be said that intraspecific chasing or fighting of schooling or assembling fishes in the small tank shows the attractive relation among individuals in natural habitats.

Thus, it is possible that any social relation, either it may be attractive or repulsive, among individuals in natural habitats assume the chasing behavior in captivity.

The interrelationship found between Girella punctata and G. melanichthys is very interesting in connection with the above-mentioned consideration. In young stage with at least less than $18 \mathrm{~cm}$ total length, these two species form together perfectly mixed schools (OKuno, 1962 b) and chase each other as if they belonged to the same species. On the other hand, adults of these fishes never form any mixed schools nor chase each other. This phenemenon is considered to support the above-mentioned thought.

The intra- and interspecific chasings in captivity may be available as clues to learn how fishes recognize other individuals or species. The dominant individual of young Girella punctata does not distinguish his subordinates from young individuals of G. melanichthys, though it distinguishes other species such as Microcanthus strigatus, Kuhlia taeniura, Abudefduf vaigiensis, etc (Tables 11-13). Young G. punctata chases Pomacentrus sp. A more frequently than Amphiprion frenatus (Table $12 \mathrm{~d}$ ), here Pomacentrus sp. A resembles G. punctata much more closely in shape and color than $A$. frenatus.

Usually chasings occur more frequently between the species resembling each other in shape and color than between those resembling each other less closely regardless to their taxonomical affinities. But naturally, the more closely related the species are, the more exactly resemble their shapes and colors one another, resultantly interspecific chasings of schooling fishes are often seen among closely related species. For example, Heniochus acuminatus scarcely chases other species of butterfly fishes, but does often H. singularius (OKuno, 1962 a) which resembles that species very closely. Chasings between Therapon oxyrhynchus and $T$. jarbua and those among adults of three species of Girella, occur more frequently than between these fishes and other species (OKuno 1963). These seem to allude that some of diurnal rocky reef fishes may discriminate other individuals by shape and color.

Furthermore, the discriminative ability of fishes changes with age as shown in the case concerning the two species of Girella. Rubinoff and SHAw (1960) report about the hybridization between the two species of silversides, Menidia menidia and $M$. beryllina that hybrids can be produced artificially under certain 
experimental conditions, but none of natural hybrids has been found in the area near Woods Hole, Massachusets*. They state that one of possible isolation mechanisms may be in such a feature that "casual observation in shoal waters revealed Menidia schools composed of only a single species, although during seining operations both species were often found in the same haul (P. 12)". SHAw (1960) reports that fry of these two species exhibit quite the similar behavior and form together compound schools.

If adult Menidia school is restricted to conspecific individuals, then the two species of Menidia and the two species of Girella are considered to share the very similar interspecific relation throughout the developmental stages. As far as I am aware no hybrids have been found between the two species of Girella under natural conditions and no attempt has ever been made on the artificial hybridization between the two.

\section{Some Aspects on the Social Behaviors of Fishes}

Social behaviors or social organizations of fishes have been studied by many students, but most of these studies were made on fishes in captivity and to clear up dominance-subordination relationships, territorial behaviors, hierarchy, territoriality and relationships between territoriality and hierarchy.

As mentioned in the preceding chapters, chasing behaviors of marine fishes in captivity are considered to be the expression of latent repulsive habit possessed intrinsically by every individual and displayed under very unusual conditions. It is considered that this repulsive character sometimes takes the form of territorial behavior or sometimes is expressed by dominance order in captivity.

If fishes have the inclination to secure some hiding places or are seeking food and if the strength of fishes differs among individuals, then the territorial behavior or dominance order will be explicated under some unusual conditions such as the small tank. Therefore, it is probably inadequate to try to elucidate the social organizations of fishes only through the social behaviors in captivity.

The hierarchy found in the Japanese monkey has the function to maintain the organization of monkey herd (Itani, 1954 and Mizunara, 1957). While, the hierarchy of fishes found in captivity does not seem to be effective to their schooling, assembling or solitary lives in natural habitats. The most stable schooling fishes showing the highest social structure among fishes never exhibit any fighting behavior in captivity, namely any social hierarchy depending upon the chasing behavior is not seen between them. Violent fightings in the limited space occur among the unstable schooling fishes. In none of the fish schools, the leadership or hierarchy have ever been observed in natural environments

* Natural hybrids between these two fishes have been found in Florida (HubBS and RANEY, 1946 and GosLine, 1948). 
and also I could not recognize these social behaviors during many diving observations under natural conditions.

\section{Schooling Behaviors of Marine Fishes in Relation to Their Habitats}

On the data presented in this and previous papers, the schooling behaviors of 36 species of rocky reef fishes are summarized in Table 23 in relation to their

Table 23. Schooling and chasing behaviors of 36 species of marine fishes in relation to their habitats.

\begin{tabular}{|c|c|c|c|c|}
\hline & Habitat & $\begin{array}{l}\text { Stability } \\
\text { of school }\end{array}$ & $\begin{array}{l}\text { Chasing behavior } \\
\text { in small tanks }\end{array}$ & Fishes \\
\hline A & $\begin{array}{l}\text { Off shore } \\
\text { Surface or } \\
\text { middle layer }\end{array}$ & Very stable & No chasing & $\begin{array}{l}\text { Caranx delicatissimus } \\
\text { Seriola quinqueradiata } \\
\text { S. purpurascens }\end{array}$ \\
\hline B & $\begin{array}{l}\text { Near reef } \\
\text { Surface or } \\
\text { middle layer }\end{array}$ & $\begin{array}{l}\text { Relatively } \\
\text { stable }\end{array}$ & No chasing & $\begin{array}{l}\text { Trachurus japonicus } \\
\text { Parapristipoma trilineatum }\end{array}$ \\
\hline $\mathrm{C}$ & $\begin{array}{l}\text { Near reef } \\
\text { Bottom }\end{array}$ & $\begin{array}{l}\text { Relatively } \\
\text { unstable }\end{array}$ & $\begin{array}{l}\text { No chasing } \\
\text { or } \\
\text { slightly } \\
\text { chasing } \\
\text { Intra-type }\end{array}$ & $\begin{array}{l}\text { Kyphosus lembus } \\
\text { Chrysophrys major } \\
\text { Lethrinus choerorhynchus } \\
\text { Lutjanus rivulatus } \\
\text { L. russelli } \\
\text { Gymnocranius griseus } \\
\text { Hapalogenys nitens } \\
\text { Siganus fuscescens }\end{array}$ \\
\hline D & In reef & Unstable & $\begin{array}{l}\text { Vigorously } \\
\text { chasing } \\
\text { Intra-type }\end{array}$ & $\begin{array}{l}\text { Apogon doederleini } \\
\text { A. notatus } \\
\text { Kuhlia taeniura } \\
\text { Girella punctata } \\
\text { G. melanichthys } \\
\text { G. mezina } \\
\text { Therapon oxyrhynchus } \\
\text { T. jarbua } \\
\text { Abudefduf sordidus } \\
\text { Microcanthus strigatus } \\
\text { Forcipiger longirostris } \\
\text { 10 spp. of Chaetodon } \\
\text { Heniochus acuminatus } \\
\text { Prionurus microlepidotus }\end{array}$ \\
\hline
\end{tabular}


inhabiting places.

Seriola purpurascens, one of the oceanic fishes, forms very stable schools. This habit is also displayed in the big tank and no chasing is exhibited in captivity. Most of fishes of the families Dorosomatidae, Dussumieridae, Clupeidae and Engraulidae of the order Clupeida and of families Scombridae and Carangidae of the order Percida are considered to belong to this category (Table 23, A).

Parapristipoma trilineatum and Trachurus japonicus form relatively stable schools. They are more stable than those of other rocky reef fishes, as this is proved by observations in the big tank; any chasing behavior has never been shown in captivity. These species occur sometimes around the reefs, but usually it is hovering in a large open area nearby (Table $23 \mathrm{~B}$ ).

Chrisophrys major and Gymnocranius griseus occur in the peripheral parts of rocky reefs and are cruising about in the area relatively larger than in cases of other reef fishes. Their schools are, however, less stable than in P. trilineatum or in $T$. japonicus, as is confirmed by the observations made in the big tank. The chasing behavior of these fishes is sometimes seen in small tanks, although the behavior is not displayed so violently (Table 23, C).

Girella punctata, G. melanichthys, Chaetodon collaris, Prionurus microlepidotus etc. are associated with rocky or coral reefs. Their schools are very unstable and occasionally they occur solitarily sometimes staying at certain places of the reef. This unstable state of the schools of these fishes is also observable in the big tank; the most active chasings are displayed in small tanks.

Thus, it is evident that the stability of fish schools and the intensity of chasing in small tanks are correlated intimately with the living places and behaviors of fishes in natural environments.

\section{Summary}

Social behaviors of 130 species of marine fishes were studied in years 1955-1962 (Table 1). Researches were made in three ways, observations in the sea (Table 2 and Figs. 1-3), in the big tank (Fig. 4) and in small tanks (Table 2). (1) Social behaviors in the sea: Four types of social behaviors are discriminated, they are schooling, assembling, solitary hovering and solitary residing (Table 4).

(2) Schooling behaviors in the big tank: Social bebaviors in the big tank are quite the same as those in the sea. Results of observations in the big tank show that the schooling behavior of marine fishes can be sorted into four categories according to the stability of schools (Tables 5, 6 and Fig. 6).

(3) Chasing behaviors in small tanks: Social behaviors are usually changed in small tanks. Generally fishes become to exhibit aggressive behaviors, although some species having a very stable schooling habit or some solitary carnivores 
do not display any fights in small tanks. Those exhibiting the most aggressive habit in the tank are small reef-associated fishes such as some species of the suborder Percina, most species of the suborders Pomacentrina, Labrina and Chaetodontina (Table 10). Three chasing types are recongized in small tanks: 1) intraspecific, 2) nonspecific and 3) interspecific. Fishes of nonspecific type chase their own species as well as other species and those of intraspecific type chase only their own species (Tables 11-21). The last is represented only by single species, Oplengathus fasciatus, of 46 observed species.

(4) Fishes reared in the big tank show the social behaviors similar to those recognized in the sea. While the fishes reared in small tanks display the chasing behavior as follows: 1) Fishes forming stable schools do not exhibit any chasing. 2) Fishes forming unstable schools display the chasing of the intraspecific type. 3) Assembling fishes show the chasing of the nonspecific type. 4) Some solitary carnivores do not display the chasing habit. 5) Solitary fishes of tender nature exhibit the chasing of the intra- or nonspecific type.

(5) Assembling fishes residing at certain limited place are naturally in some social relation with other species living nearby through their occupying spaces as well as with individuals of their own species. While, schooling fishes with a hovering nature are not in any social relations with other species through their occupying spaces, although they are in a close intraspecific social relations, in natural habitats, either they may be attractive or repulsive.

(6) Young Girella punctata and G. melanichthys form together perfectly mixed schools in the sea, and they chase one another in captivity without discriminating the specific difference. However, their adults form respectively monospecific schools and never chase individuals of other species. Thus young Girella seem to lack the ability to recognize the specific differences, though adults discern the differences.

(7) After all, the chasing behavior of schooling fishes in the tank is an abnormal one evoked under the unusual condition of small space. No aggresive behaviors have ever been seen in the sea on schooling fishes in schools. Thus, it is clear that such hierarchy, leadership or other social relationships observed in captivity are not available to schools of fishes in natural habitats.

\section{REFERENCE}

AlleE, W. C. and Dickinson, J. C. 1954. Dominance and subordination in the smooth dogfish, Mustelus canis (MitchILL). Physiol. Zoöl., $27: 356-364$.

ARAGA, Ch. 1963. Young forms of three damsel fishes belonging to the genus Tetradrachmum inhabiting southern part of Japan. Publ. Seto Mar. Biol. Lab., 11 : 157-163.

BERMAN, H. M. 1945*. The effect of various groupings of normal and forebrainless gold fish on their learning ability. Master's Thesis, University of Chicago.

BRADDOCK, J. C. 1945 . Some aspects of the dominance-subordination relationship in the fish Platypoecilus maculatus. Physiol. Zoöl., 18: 176--195. 
BRADDOCK, J. C. 1949. The effects of prior residence upon dominance in the fish Platypoecilus maculatus. Ibid, $22: 161-169$.

Breder, C. M. 1959. Studies on social groupings in fishes. Bull. Amer. Mus. Nat. Hist., 117 : 397-481.

- and HALPERN, F. 1946. Innate and acquired behavior affecting aggregations of fishes. Physiol. Zoöl., $19: 154-190$.

Collecting Group of Suma AquARIUM. 1962. Collecting surveys of Suma Aquarium. Jour. Jap. Asso. Zoological Gardens and Aquariums, 4:41-49. (in Japanese)

DAVENPORT, D. and NorRis, K. S. 1958. Observations on the symbiosis of the sea anemone Stoichactis and the pomacentrid fish, Amphiprion percula. Biol. Bull., 115 : 397-410.

FusE, S. 1962a. The animal communities in the Zostera belt. Physiol. Ecol., 11: 1-22. (in Japanese)

Japanese)

Fuse, S., Yamazi, I. and HARADA, E. 1958. A study on the productivity of the Tanabe Bay (Part I). I. A oceanographic conditions of the Tanabe Bay. Results of the survey in the autumn of 1956. Rec. Oceano. Works in Japan, Special No. 2: 3-9.

Gosline, W. A. 1948. Speciation in the fishes of the genus Menidia. Evolution, 2: 306-313.

GohaR, H. W. F. 1948. Commensalism between fish and anemone. Publ. Mar. Sta. Gardaqu, 63 : 5-44.

GREENBERG, B. 1947. Some relations between territory, social hierarchy, and leadership in the green sunfish (Lepomis cyanellus). Physiol. Zoöl., 20: 267-299.

HALE, E. B. 1956a. Social facilitation and forebrain function in maze performance of green sunfish, Lepomis cyanellus. Ibid., 29: 93-107.

1956b. Effects of forebrain lesions on the aggressive behavior of green sunfish, Lepomis cyanellus. Ibid., $29: 107-127$.

HARAdA, E. 1962. A contribution to the biology of the black rock fish, Sebastes inermis CUviER et Valenciennes. Publ. Seto Mar. Biol. Lab., 10:307-361.

Hiatt, R. W. and Strasburg, D. W. 1960. Ecological relationships of the fish fauna on coral reefs of the Marshall Islands. Ecol. Monogr., 30:65-127.

Hillowits, S. 1945*. The effects of forebrain removal on learning in gold fish. Master's Thesis, Univ. of Chicago.

Hubbs, C. L. and Raney, E. C. 1946. Endemic fish fauna of Lake Waccamaw, North Carolina. Misc. Pub. Mus. Zool. Univ. Michigan, No. 65: 1-30.

ITANI, J. 1954. "Takasaki-yama no saru”. Tokyo. (in Japanese)

KALLEBERG, H. 1958. Observations in a stream tank of territoriality and competition in juvenile salmon and trout (Salmo salar L. and S. trutta L.). Inst. Freshwater Res. Drottningholm, Rep. No. 39 : 55-98.

Kawabata, M. 1954. Socio-ecological studies on the killi-fish, Aplocheilus latipes. I. General remarks on the social behavior. Jap. J. Ecol,, 4: 109-113. (in Japanese)

KAWANABE, H. 1957. Social behaviour and production of a salmon-like fish, Plecoglossus altivelis, or Ayu, with reference to it population density. Ibid., $7: 131-137$. (in Japanese)

1958. On the significance of the social structure for the mode of density effect in a salmon-like fish, "Ayu", Plecoglossus altivelis TEMminck et Schlegel. Mem. Coll. Sci., Univ. Kyoto, (B), $25: 171-180$.

1959. Food competition among fishes in some rivers of Kyoto prefecture, Japan. Ibid., $26: 253-268$

1960. An opinion on the study of the lotic animal community. Physiol. Ecol., 9: 1-10. (in Japanese)

, Miyadi, D., Mori, S., Harada, E., Mizuhara, H. and Ohgushi, R. 1956. Ecology of natural stock of Ayu, Plecoglossus altivelis. Contr. Physiol. Ecol. Kyoto Univ., No. 79 : 1-37. (in Japanese) 
Kawanabe, H., Mizuno, N., Miyadi, D., Mori, S., Ohgushi, R. and Nishimura, N. 1957. Ecology of natural stock of salmon-like fish, Ayu. II. The mode of life in relation to its population. density. Physiol. Ecol., $7: 145-167$. (in Japanese)

, MORI, S. and MizUNo, N. 1957. Modes of utilizing the river-pools by a salmonlike fish, Plecoglossus altivelis or Ayu, in relation to its population density. Jap. J. Ecol., 7 : 22-26. (in Japanese)

1959. On the food economy of "Ayu" fish with relation to the production of algae. Physiol. Ecol., 8: 117-123. (in Japanese)

MAGNuson, J. J. 1962. An analysis of aggressive behavior, growth, and competition for food and space in Medaka (Oryzias latipes (Pisces, Cyprinodontidae)). Canadian Jour. Zool., 40: 313-363.

MANSUEt, R. 1963. Symbiotic behavior between small fishes and jelly fishes, with new data on that between the stromateid, Peprilus alepidotus, and the scyphomedusa, Chrysaora quinquecirrha. Copeia, 1963 (1): 40-80.

Matsubara, K. 1955. Fish morphology and hierarchy. I-III. Tokyo (in Japanese).

Mryadi, D. and HAyAmi, S. 1958. A study on the productivity of the Tanabe Bay (Part I). I-VII. Rec. Oceano. Works in Japan, Special No. 2: 1-56.

- KawabatA, M. and UedA, K. 1952. Standard density of "Ayu" Plecoglossus altivelis on the basis of its behaviour and grazing unit in area. Contr. Physiol. Ecol. Kyoto Univ., No. $75: 1-34$. (in Japanese)

MrzUhaRA, H. 1957. "Nihon-zaru". Kyoto. (in Japanese)

MORI, S. 1956. Social organization of a group of young girelloid fish, Girella punctata GRAY, confined in a tide-pool, with special reference to the relation between social hierarchy and territorial system. Jap. J. Ecol., 5: 145-150. (in Japanese)

Newman, M. A. 1956. Social behavior and interspecific competition in two trout species. Physiol. Zoöl., $29: 64-81$.

OKuno, R. 1956a. Modes of life of some reef fishes with references to their microhabitats, food habits and social behaviors. Contr. Physiol. Ecol. Kyoto Univ., No. 80 : 1-15. (in Japanese)

- 1956b. A schooling habit of young Girella punctata, a common reef fish along the Japanese coast. Jap. J. Ecol, 6: 99-102. (in Japanese)

1962a. Intra- and interspecific relations of saltwater fishes in aquarium. I. Butterfly fishes. Ibid., $12: 129-133$. (in Japanese)

1962b. Distribution of youngs of two reef fishes, Girella punctata GRAY and $G$. melanichthys (RICHARDSON), in Tanabe Bay and the relationship found between their schooling behaviors. Publ. Seto Mar. Biol. Lab., 10: 293-306.

1963. Intra- and interspecific relations of saltwater fishes in aquarium. II. Fishes belonging to order Percida and others. Jap. J. Ecol., 13: 46-53. (in Japanese)

$\longrightarrow$ and AOKI, T. 1959. Some observations on the symbiosis between the pomacentrid fish and the sea anemone. Jour. Jap. Asso. Zoological Gardens and Aquariums, 1: 8-11. (in Japanese)

, Fuse, S. and Harada, E. 1958. A study on the productivity of the Tanabe Bay (Part I). V. Distribution and abundance of rocky reef fishes in the Tanabe Bay. Rec. Oceano. Works in Japan, Special No. $2: 36-42$.

-. KURIO, T. and NishigUCHI, M. 1960. Underwater observations of reef fishes with reference to their micro-habitats and behaviours. 1. Pomacanthus semicirculatus (CUVIER et VAlENCIENNES). Jour. Jap. Asso. Zoological Gardens and Aquariums, 2: 95-97. (in Japanese) - NishiguchI, M. and KURIO, T. 1961. Underwater observations of reef fishes with reference to their micro-habitats and behaviours. II. 2. Doryrhamphus sp., 3. Diademichthys lineatus, 4. Stenopus hispidus. Ibid., 3:16-17. (in Japanese)

1962. Underwater observations of reef fishes with reference to their micro-habitats and behaviors. III. 5. Longnosed butterfly fish, Forcipiger 
longirostris. Ibid., $4: 50-53$. (in Japanese)

RuBINOFF, I. and SHAw, E. 1960. Hybridization in two sympatric species of atherinid fishes, Menidia menidia (LINNAEus) and Menidia beryllina (COPE). Amer. Mus. Novitates, No. 1999: 1-13.

SHAw, H. 1960. The development of schooling behavior in fishes. Physiol. Zoöl., 33: 79-86. 1961. The development of schooling in fishes. II. Ibid., $34: 263-272$.

Schultz, L. P., Chapman, W. M., Lachner, E. A. and Woods, L. P. 1960. Fishes of the Marshall and Marianas Islands. Vol. 2. U.S. Nat, Mus., Bull. 202 : 1-438.

WeLty, J. C. 1934. Experimental explorations into group behavior of fishes: a study of the influences of the group on individual behavior. Physiol. Zoöl., $7: 85-128$. 